\title{
Factors controlling nitrous oxide emissions from managed northern peat soils with low carbon to nitrogen ratio
}

\section{Maarit Liimatainen ${ }^{\mathrm{a}, *}$, Carolina Voigt ${ }^{\mathrm{a}}$, Pertti J. Martikainen ${ }^{\mathrm{a}}$, Jyrki Hytönen ${ }^{\mathrm{b}}$, Kristiina Regina ${ }^{\mathrm{c}}$, Hlynur Óskarsson ${ }^{\mathrm{d}}$, Marja Maljanen ${ }^{\mathrm{a}}$}

${ }^{a}$ University of Eastern Finland, Department of Environmental and Biological Sciences, P.O. Box 1627, FI-70211 Kuopio, Finland

b Natural Resources Institute Finland (Luke), Natural Resources, Teknologiakatu 7, FI-67100 Kokkola, Finland

${ }^{\mathrm{c}}$ Natural Resources Institute Finland (Luke), Bioeconomy and Environment, Tietotie 4, FI-31600 Jokioinen, Finland

${ }^{\mathrm{d}}$ Agricultural University of Iceland, Faculty of Agricultural and Environmental Sciences, 311 Hvanneyri, Iceland

\section{A R T I C L E I N F O}

\section{Keywords:}

$\mathrm{N}_{2} \mathrm{O}$

Drained peatlands

Land-use

Phosphorus

Copper

$\mathrm{C} / \mathrm{N}$ ratio

\begin{abstract}
A B S T R A C T
Managed northern peatlands are an important source of the strong greenhouse gas nitrous oxide $\left(\mathrm{N}_{2} \mathrm{O}\right)$. However, $\mathrm{N}_{2} \mathrm{O}$ emissions from these managed peatlands display a high spatial variability, and processes governing $\mathrm{N}_{2} \mathrm{O}$ production and emissions from these ecosystems are still not well understood. To constrain the factors regulating $\mathrm{N}_{2} \mathrm{O}$ emissions from managed northern peat soils, we determined a wide set of soil physical and chemical properties of peatlands with different management histories spread across Finland, Sweden and Iceland. We included eleven peatland sites with available in situ $\mathrm{N}_{2} \mathrm{O}$ flux data, and complemented our analyses with detailed measurements of soil nitrogen $(\mathrm{N})$ cycling processes such as $\mathrm{N}_{2} \mathrm{O}$ production, gross $\mathrm{N}$ mineralization and gross nitrification and, in addition, soil microbial biomass. This study included drained peatlands with different land-use types and management intensities, comprising forested, cultivated or only drained peatlands and afforested or abandoned agricultural peatlands. All selected peatland sites displayed a low soil carbon to nitrogen $(\mathrm{C} / \mathrm{N})$ ratio of $15-27$, traditionally used to predict high $\mathrm{N}_{2} \mathrm{O}$ emissions. Despite the narrow $\mathrm{C}$ / $\mathrm{N}$ range, the $\mathrm{N}_{2} \mathrm{O}$ emissions at our sites varied greatly within and between land-use groups, ranging from 0.03 to $2.38 \mathrm{~g} \mathrm{~N} \mathrm{~m}^{-2} \mathrm{y}^{-1}$. Thus, our findings provide valuable insights into the regulatory factors underlying the variability in $\mathrm{N}_{2} \mathrm{O}$ emissions and show that a low $\mathrm{C} / \mathrm{N}$ ratio in managed peatlands cannot be used to predict high $\mathrm{N}_{2} \mathrm{O}$ emissions. Instead, our results demonstrate that higher $\mathrm{N}_{2} \mathrm{O}$ emissions are linked to higher peat phosphorus (P) and copper $(\mathrm{Cu})$ content, suggesting that low $\mathrm{P}$ and $\mathrm{Cu}$ concentrations can limit $\mathrm{N}_{2} \mathrm{O}$ production in peat even with sufficient $\mathrm{N}$ availability. While known factors such as soil moisture, oxygen content and the degree of peat humification partially explained the variability in $\mathrm{N}_{2} \mathrm{O}$ emissions, this study directly links soil $\mathrm{P}$ and $\mathrm{Cu}$ availability to $\mathrm{N}_{2} \mathrm{O}$ production processes. The availability of $\mathrm{P}$ and especially $\mathrm{Cu}$ seemed to promote nitrification activities, thereby increasing $\mathrm{N}_{2} \mathrm{O}$ production. Our study highlights the link between $\mathrm{N}_{2} \mathrm{O}$ emissions and soil P and $\mathrm{Cu}$ availability and the strong coupling of the soil $\mathrm{N}$ and $\mathrm{P}$ cycles in peatlands, which is to date severely understudied.
\end{abstract}

\section{Introduction}

Nitrous oxide $\left(\mathrm{N}_{2} \mathrm{O}\right)$, carbon dioxide $\left(\mathrm{CO}_{2}\right)$ and methane $\left(\mathrm{CH}_{4}\right)$ are important greenhouse gases. The global warming potential of $\mathrm{N}_{2} \mathrm{O}$ is 265 times greater than that of $\mathrm{CO}_{2}$ and almost ten times greater than that of $\mathrm{CH}_{4}$ (100-year time horizon; Myhre et al., 2013). With increasing application of nitrogen $(\mathrm{N})$ fertilizers, the tropospheric $\mathrm{N}_{2} \mathrm{O}$ concentration is rising (Canfield et al., 2010; Davidson, 2012; Vitousek et al., 1997). While $\mathrm{N}_{2} \mathrm{O}$ is stable in the troposphere, in the stratosphere $\mathrm{N}_{2} \mathrm{O}$ participates in reactions destroying the ozone layer (Ravishankara et al., 2009). The main natural $\mathrm{N}_{2} \mathrm{O}$ sources are terrestrial ecosystems where $\mathrm{N}_{2} \mathrm{O}$ is produced by soil microbial processes. From all anthropogenic $\mathrm{N}_{2} \mathrm{O}$ sources, including biomass burning and fossil fuels, agriculture is the most important (Fowler et al., 2009). Anthropogenic $\mathrm{N}_{2} \mathrm{O}$ emissions contribute with $30-45 \%$ to the total $\mathrm{N}_{2} \mathrm{O}$ emissions (IPCC, 2013), and over $80 \%$ of the anthropogenic emissions are derived from agriculture (Davidson, 2012).

Peatlands cover only $3 \%$ of the Earth's surface, but they store one third of the global organic carbon pool (Köchy et al., 2015; Strack, 2008). Among managed Northern soils, drained peatlands are one of

\footnotetext{
* Corresponding author.

E-mail address: maarit.liimatainen@uef.fi (M. Liimatainen).
} 
Table 1

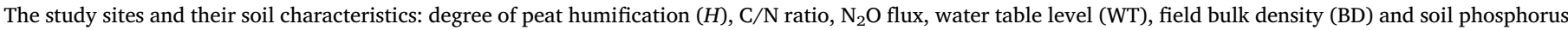

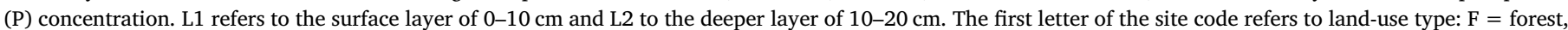

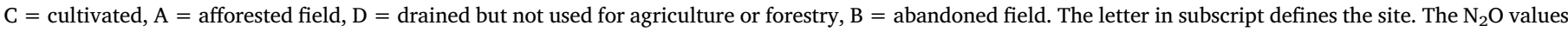
are annual averages and in all cases \pm denotes standard deviation.

\begin{tabular}{|c|c|c|c|c|c|c|c|c|c|c|c|c|c|}
\hline \multirow[t]{2}{*}{ Land-use } & \multirow[t]{2}{*}{ Site } & \multirow[t]{2}{*}{ Location } & \multirow[t]{2}{*}{ Country } & \multirow[t]{2}{*}{ Soil sampling } & \multicolumn{2}{|l|}{$H^{*}$} & \multicolumn{2}{|l|}{$\mathrm{C} / \mathrm{N}$ ratio } & \multirow{2}{*}{$\frac{\mathrm{N}_{2} \mathrm{O} \text { flux }}{\left(\mathrm{g} \mathrm{N} \mathrm{m}^{-2} \mathrm{y}^{-1}\right)}$} & \multirow{2}{*}{$\frac{\mathrm{WT}}{(\mathrm{cm})}$} & \multirow{2}{*}{$\frac{\mathrm{BD}}{0-20 \mathrm{~cm}}$} & \multicolumn{2}{|c|}{$\mathrm{P}\left(\mathrm{mg} \mathrm{kg}^{-1}\right)$} \\
\hline & & & & & L1 & $\mathrm{L} 2$ & L1 & $\mathrm{L} 2$ & & & & L1 & $\mathrm{L} 2$ \\
\hline \multirow[t]{2}{*}{ Forests } & $\mathrm{F}_{\mathrm{S}}$ & $63^{\circ} 54^{\prime} \mathrm{N}, 23^{\circ} 56^{\prime} \mathrm{E}$ & Finland & $18 / 06 / 2012$ & $7-8$ & 8 & $23 \pm 0.0$ & $22 \pm 0.4$ & $1.43 \pm 0.59^{\mathrm{a}}$ & $-41^{\mathrm{a}}$ & $0.20^{\mathrm{a}}$ & 943 & 1260 \\
\hline & $\mathrm{F}_{J}$ & $63^{\circ} 52 ` \mathrm{~N}, 23^{\circ} 44^{\prime} \mathrm{E}$ & Finland & $18 / 07 / 2011$ & $6-7$ & $7-8$ & $19 \pm 0.1$ & $18 \pm 0.1$ & $0.07 \pm 0.03^{\mathrm{a}}$ & $-36^{\mathrm{a}}$ & $0.17^{\mathrm{a}}$ & 861 & 1340 \\
\hline \multirow{3}{*}{$\begin{array}{l}\text { Cultivated } \\
\text { fields }\end{array}$} & $\mathrm{C}_{\mathrm{S}}$ & $63^{\circ} 54^{\prime} \mathrm{N}, 23^{\circ} 56^{\prime} \mathrm{E}$ & Finland & $22 / 09 / 2011$ & $8-9$ & $8-9$ & $17 \pm 0.0$ & $17 \pm 0.0$ & $2.38 \pm 1.49^{\mathrm{b}}$ & $-60^{\mathrm{b}}$ & $0.22^{\mathrm{b}}$ & 3280 & 3060 \\
\hline & $\mathrm{C}_{\mathrm{I}}$ & $64^{\circ} 34^{\prime} \mathrm{N}, 21^{\circ} 46^{\prime} \mathrm{W}$ & Iceland & $12 / 07 / 2011$ & $7-8$ & $7-8$ & $15 \pm 0.1$ & $16 \pm 0.1$ & $0.03^{c}$ & & $0.23^{g}$ & 1660 & 964 \\
\hline & $\mathrm{C}_{\mathrm{K}}$ & $60^{\circ} 54^{\prime} \mathrm{N}, 23^{\circ} 31^{\prime} \mathrm{E}$ & Finland & $23 / 04 / 2012$ & 9 & 9 & $23 \pm 0.2$ & $22 \pm 0.1$ & $0.73 \pm 0.12^{\mathrm{d}}$ & $-82^{\mathrm{d}}$ & $0.48^{\mathrm{h}}$ & 1470 & 1560 \\
\hline \multirow{3}{*}{$\begin{array}{l}\text { Afforested } \\
\text { fields }\end{array}$} & $A_{L}$ & $64^{\circ} 06^{\prime} \mathrm{N}, 24^{\circ} 21^{\prime} \mathrm{E}$ & Finland & $23 / 08 / 2011$ & 7 & $7-8$ & $17 \pm 0.1$ & $18 \pm 0.2$ & $2.14 \pm 0.60^{\mathrm{e}}$ & $-52^{\mathrm{e}}$ & $0.25^{\mathrm{e}}$ & 2870 & 1760 \\
\hline & $A_{R}$ & $64^{\circ} 06^{\prime} \mathrm{N}, 24^{\circ} 21^{\prime} \mathrm{E}$ & Finland & $23 / 08 / 2011$ & $8-9$ & $8-9$ & $24 \pm 0.2$ & $27 \pm 0.1$ & $0.07 \pm 0.07^{\mathrm{e}}$ & $-25^{\mathrm{e}}$ & $0.25^{\mathrm{e}}$ & 1640 & 1190 \\
\hline & $A_{G}$ & $58^{\circ} 23^{\prime} \mathrm{N}, 12^{\circ} 09^{\prime} \mathrm{E}$ & Sweden & 09/05/2011 & $7-8$ & $9-10$ & $25 \pm 0.2$ & $27 \pm 0.0$ & $0.26 \pm 0.08^{f}$ & $-80^{f}$ & $0.20^{\mathrm{i}}$ & 1000 & 862 \\
\hline Drained & $\mathrm{D}_{\mathrm{I}}$ & $64^{\circ} 34^{\prime} \mathrm{N}, 21^{\circ} 46^{\prime} \mathrm{W}$ & Iceland & $12 / 07 / 2011$ & $5-6$ & $6-7$ & $15 \pm 0.0$ & $16 \pm 0.1$ & $0.04^{\mathrm{c}}$ & & $0.34^{g}$ & 956 & 801 \\
\hline \multirow{2}{*}{$\begin{array}{l}\text { Abandoned } \\
\text { fields }\end{array}$} & $\mathrm{B}_{\mathrm{A}}$ & $63^{\circ} 54^{\prime} \mathrm{N}, 23^{\circ} 56^{\prime} \mathrm{E}$ & Finland & $25 / 04 / 2012$ & $8-9$ & $8-9$ & $20 \pm 0.2$ & $23 \pm 0.0$ & $0.41 \pm 0.17^{\mathrm{e}}$ & $-35^{\mathrm{e}}$ & $0.30^{\mathrm{e}}$ & 1460 & 1270 \\
\hline & $\mathrm{B}_{\mathrm{B}}$ & $63^{\circ} 54^{\prime} \mathrm{N}, 23^{\circ} 56^{\prime} \mathrm{E}$ & Finland & $25 / 04 / 2012$ & $9-10$ & $9-10$ & $25 \pm 0.5$ & $26 \pm 1.3$ & $1.42 \pm 0.68^{\mathrm{e}}$ & $-51^{e}$ & $0.42^{\mathrm{e}}$ & 944 & 1010 \\
\hline
\end{tabular}

* Degree of humification was estimated according to von Post (1922).

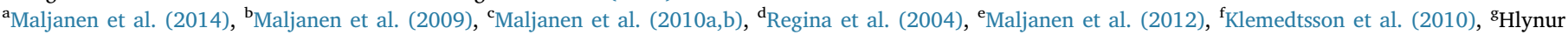
Óskarsson; personal communication, ${ }^{\mathrm{h}}$ Lohila et al. (2003), ${ }^{\mathrm{i}}$ Björk et al. (2010).

the largest emitters of $\mathrm{N}_{2} \mathrm{O}$ (Maljanen et al., 2010a) due to their high $\mathrm{N}$ stocks and high $\mathrm{N}$ mineralization rates, which are the key for the high $\mathrm{N}_{2} \mathrm{O}$ production in these soils (Strack, 2008). In the Northern latitudes, most of the peatlands are located in Russia, Canada, USA and the Nordic countries of Europe. Agricultural use, forestry, and peat extraction require drainage of peatlands, but the extent of drainage varies. In most countries agriculture is the main use of peatlands (Strack, 2008). In Finland, however, only $1 \%$ of peatlands are currently used for agriculture (Myllys and Sinkkonen, 2004), whereas over half of the peatlands have been drained for forestry (Strack, 2008).

Nitrous oxide is produced by soil microbial processes, especially during nitrification and denitrification (Butterbach-Bahl et al., 2013). During ammonium oxidation $\mathrm{N}_{2} \mathrm{O}$ can be produced through two pathways, either as a by-product in the first step of nitrification or during nitrifier denitrification (De Boer and Kowalchuk, 2001; Wrage et al., 2001). During denitrification, nitrate $\left(\mathrm{NO}_{3}{ }^{-}\right)$is reduced to $\mathrm{N}_{2} \mathrm{O}$ by facultative anaerobic bacteria, which can be further reduced to $\mathrm{N}_{2}$, depending on the environmental conditions such as $\mathrm{pH}$ (Šimek and Cooper, 2002) and oxygen $\left(\mathrm{O}_{2}\right)$ status (Khalil et al., 2004). Although nitrification and denitrification are the main known processes for $\mathrm{N}_{2} \mathrm{O}$ production in soils, other less well studied processes can also produce $\mathrm{N}_{2} \mathrm{O}$ in soils (Butterbach-Bahl et al., 2013).

Natural peatlands display negligible $\mathrm{N}_{2} \mathrm{O}$ emissions and can even act as net sinks for $\mathrm{N}_{2} \mathrm{O}$. After drainage, however, when the peat is exposed to $\mathrm{O}_{2}, \mathrm{~N}_{2} \mathrm{O}$ emissions can increase strongly (Martikainen et al., 1993; Regina et al., 1996). Exposure to $\mathrm{O}_{2}$ accelerates organic matter (OM) decomposition and $\mathrm{N}$ mineralization, as well as nitrification. After drainage, the increase in $\mathrm{N}_{2} \mathrm{O}$ emissions is higher in nutrient rich than in nutrient poor peatlands. Cultivated peat soils, which are generally rich in nutrients due to fertilization, show the highest $\mathrm{N}_{2} \mathrm{O}$ emissions among drained peatlands (Kasimir-Klemedtsson et al., 1997; Maljanen et al., 2010a). Although only $10 \%$ (250 000 ha) of the total cropland area in Finland is on peat soils, $\mathrm{N}_{2} \mathrm{O}$ emissions from cultivated peat soils account for $43 \%$ of $\mathrm{N}_{2} \mathrm{O}$ emissions from agricultural soils (Statistics Finland, 2017). Nitrous oxide emissions from cultivated peatlands are generally 5-20 times higher than those from peatland forests (Martikainen et al., 1993; Kasimir-Klemedtsson et al., 1997). Yet, while $\mathrm{N}_{2} \mathrm{O}$ emissions from peatland forests are often negligible (Ojanen et al., 2010), some peatland forests display $\mathrm{N}_{2} \mathrm{O}$ emissions that are nearly as high as those from cultivated peat soils (Maljanen et al., 2010a, 2010b).
Drainage and associated lowering of the water table is a key factor enhancing $\mathrm{N}_{2} \mathrm{O}$ emissions from peatlands (Martikainen et al., 1993). Therefore, regulating the water table level in managed peatlands is suggested to be the most efficient way to mitigate $\mathrm{N}_{2} \mathrm{O}$ emissions (e.g. Regina et al., 2015). The soil $\mathrm{C} / \mathrm{N}$ ratio is often used to predict the magnitude of $\mathrm{N}_{2} \mathrm{O}$ emissions, which are generally highest in drained peatlands with a low $(<30) \mathrm{C} / \mathrm{N}$ ratio (Klemedtsson et al., 2005; Leppelt et al., 2014; Maljanen et al., 2010a). In drained peatland forests $\mathrm{N}_{2} \mathrm{O}$ emissions have been shown to decrease straightforwardly with increasing $\mathrm{C} / \mathrm{N}$ ratio (Klemedtsson et al., 2005). However, over the wide variety of land-use types and management practices in northern peatlands and other organic soils, $\mathrm{N}_{2} \mathrm{O}$ emissions display a high spatial and temporal variability (Leppelt et al., 2014; Maljanen et al., 2010a; Tiemeyer et al., 2016): even within the narrow $\mathrm{C} / \mathrm{N}$ range of 15-30, which is considered the optimum range for high $\mathrm{N}_{2} \mathrm{O}$ production and emissions, $\mathrm{N}_{2} \mathrm{O}$ fluxes vary greatly.

The aim of this study was to identify factors explaining the high variability in $\mathrm{N}_{2} \mathrm{O}$ fluxes from managed northern peatlands within this narrow $\mathrm{C} / \mathrm{N}$ range, where $\mathrm{N}_{2} \mathrm{O}$ production is clearly not limited by $\mathrm{N}$ availability. We selected eleven sites with available year-round in situ $\mathrm{N}_{2} \mathrm{O}$ flux data and a low $(<27) \mathrm{C} / \mathrm{N}$ ratio. The selected sites were managed peatlands under different land-use, and were spread across Finland, Sweden and Iceland. We determined a wide set of peat physical-chemical characteristics, including trace elements and macronutrients, for two soil layers, $0-10$ and $10-20 \mathrm{~cm}$, of each site. We complemented these soil analyses with a detailed array of process-based measurements related to $\mathrm{N}$-cycling, including $\mathrm{N}_{2} \mathrm{O}$ production (both layers), gross $\mathrm{N}$ mineralization $(10-20 \mathrm{~cm})$ and gross nitrification $(10-20 \mathrm{~cm})$, as well as soil microbial biomass C $(10-20 \mathrm{~cm})$. The aim of our study was to investigate whether these soil physical, chemical, and biological parameters provide new insights for predicting $\mathrm{N}_{2} \mathrm{O}$ emissions from managed peatlands that cannot be fully explained by the $\mathrm{C}$ / $\mathrm{N}$ ratio.

\section{Materials and methods}

\subsection{Study sites}

The site selection was based on the data availability of annual $\mathrm{N}_{2} \mathrm{O}$ emissions, including wintertime emissions, since a major part of the 
annual $\mathrm{N}_{2} \mathrm{O}$ emissions can occur during wintertime (Maljanen et al., $2010 \mathrm{~b})$. In addition, chosen sites had a peat $\mathrm{C} / \mathrm{N}$ ratio of $15-30$ - the optimum range for $\mathrm{N}_{2} \mathrm{O}$ emissions (Klemedtsson et al., 2005). Soil samples were collected from eleven drained peatland sites with various land-use practices (Table 1): a) two forested (F) peat soils in Finland $\left(\mathrm{F}_{\mathrm{S}}, \mathrm{F}_{\mathrm{J}}\right)$; b) three cultivated $(\mathrm{C})$ peat soils, two in Finland $\left(\mathrm{C}_{\mathrm{S}}, \mathrm{C}_{\mathrm{K}}\right)$ and one in Iceland $\left.\left(C_{I}\right) ; c\right)$ three afforested (A) fields, two in Finland $\left(A_{L}, A_{R}\right)$ and one site in Sweden $\left(A_{G}\right)$; d) one drained (D) site in Iceland not used for agriculture or forestry $\left(D_{I}\right)$ and e) two abandoned (B) fields in Finland $\left(B_{A}, B_{B}\right)$. The subscript in the codes identifies the study site. More detailed information on drainages, peat depths and dominant tree and understory plant species can be found in Table S1.

Soil samples from the sites (Table 1 ) were taken at two depths (0-10 and $10-20 \mathrm{~cm}$ ). Except for the particle density, all physical and chemical analyses were determined for both soil layers. Process-based measurements (gross $\mathrm{N}$ mineralization, gross nitrification, soil microbial biomass $\mathrm{C}$ ) were limited to the deeper soil layer.

\subsection{Soil physical and chemical properties}

Soils were homogenized manually and large, visible roots were removed. The degree of humification $(H)$ was determined using the von Post (1922) approach. Soil gravimetric water content (GWC) was determined by drying soils at $+65{ }^{\circ} \mathrm{C}$ for $24 \mathrm{~h}$. Soil $\mathrm{pH}_{\mathrm{H} 2 \mathrm{O}}$ and electrical conductivity (EC) were measured from milli-Q- $\mathrm{H}_{2} \mathrm{O}$-soil slurry $(1: 2 \mathrm{v} / \mathrm{v})$ with pH (WTW pH 240) and EC (Fennolab) meters, respectively. The soil organic matter content $(\mathrm{OM})$ was determined by loss on ignition at $550{ }^{\circ} \mathrm{C}$. Nitrate $\left(\mathrm{NO}_{3}{ }^{-}\right)$and nitrite $\left(\mathrm{NO}_{2}{ }^{-}\right)$concentrations were analyzed from water extracts with an ion chromatograph (DX 120, Dionex Corporation, USA), and ammonium $\left(\mathrm{NH}_{4}{ }^{+}\right)$concentrations were measured from $1 \mathrm{M} \mathrm{KCl}$ extracts with a spectrophotometer (Ultrospec 3000 Pro, Biochrom, UK). Analyses of $\mathrm{NO}_{3}{ }^{-}, \mathrm{NO}_{2}{ }^{-}$and $\mathrm{NH}_{4}{ }^{+}$are described in more detail by Liimatainen et al. (2014). Dissolved organic carbon (DOC) was extracted using $0.25 \mathrm{M} \mathrm{K}_{2} \mathrm{SO}_{4}$ and analyzed with a TOC analyzer (Shimadzu TOC Vcph, Shimadzu Scientific, Japan). The soil C and $\mathrm{N}$ content as well as the soil $\delta^{15} \mathrm{~N}$ and $\delta^{13} \mathrm{C}$ isotopic signatures were analyzed with an isotope ratio mass spectrometer (IRMS Thermo Finningan Advantage, Germany) coupled to an elemental analyzer (Flash EA 1112, Italy) in University of Jyväskylä, Finland. A certified birch leaf standard (Elemental Microanalysis, UK) was used as a reference in $\mathrm{C}, \mathrm{N}, \delta^{15} \mathrm{~N}$ and $\delta^{13} \mathrm{C}$ analyses. The total concentration of trace elements and macronutrients (Al, B, Ca, Cd, Cr, Cu, Fe, K, Na, Ni, Mg, Mn, P, Pb, $\mathrm{S}, \mathrm{Zn})$ were analyzed with nitric acid/hydrogen peroxide $\left(\mathrm{HNO}_{3} / \mathrm{H}_{2} \mathrm{O}_{2}\right)$ extraction combined with microwave digestion. Extracts were analyzed with inductively coupled plasma atomic emission spectroscopy (ICPAES) (Table S2).

Bulk density values listed in Table 1 were determined in the field from intact soil cores. Because we conducted laboratory experiments using homogenized soil, we determined the bulk density also for homogenized peat in the laboratory. Soil particle density $(n=5)$ was determined by boiling dried and ground soil in pycnometers with milli$\mathrm{Q}-\mathrm{H}_{2} \mathrm{O}$ to get rid of $\mathrm{O}_{2}$. Soil particle density (PD) was calculated using water density, soil dry weight and mass and volume of the pycnometer. From PD and BD we calculated total porosity (TP) of the soil. Further, water filled pore space (WFPS) was calculated based on the volumetric water content, $\mathrm{PD}$ and $\mathrm{BD}$.

\subsection{Soil microbial biomass}

To determine the soil microbial biomass C (MBC), we applied the substrate induced respiration (SIR) method (Anderson and Domsch, 1978). For this purpose, the moisture was adjusted to $60 \%$ of the maximum water holding capacity (WHC). Soils having a water content of $>60 \%$ WHC were dried at room temperature to achieve a moisture content close to the desired 60\% WHC. The amount of glucose needed to achieve the maximum respiration was determined separately for each soil. Fresh soil that equals a dry weight of $2 \mathrm{~g}$ was weighed into $550 \mathrm{ml}$ flasks in 5 replicates. After addition of the glucose solution, the WHC of the soil was $60 \%$. Flasks were kept open for $30 \mathrm{~min}$, aerated with a fan for $1 \mathrm{~min}$ and then closed with a septum and a screw cap. Laboratory air was added to create an overpressure allowing gas sampling. Soils were incubated at room temperature for $165 \mathrm{~min}$ and gas samples were taken four times during the incubation from the headspace using a $60 \mathrm{ml}$ polypropylene syringe. Gas samples were immediately injected into pre-evacuated $12 \mathrm{ml}$ glass vials (Labco, Exetainer ${ }^{\circ}$ ) and the $\mathrm{CO}_{2}$ concentration was analyzed on the same day with a gas chromatograph (GC, Agilent 6890N Network GC System, Agilent Technologies, USA). The MBC results were calculated from the respiration rates using the formula by Anderson and Domsch (1978).

\subsection{Gross $N$ mineralization and nitrification rates}

Gross $\mathrm{N}$ mineralization rates were determined once during one growing season. A pool dilution method (Kirkham and Bartholomew, $1954,1955)$ was used to study the gross $\mathrm{N}$ mineralization rate as described by Marushchak et al. (2011). Fresh homogenized and sieved soils $(\mathrm{n}=6)$ that were pre-incubated at $+15{ }^{\circ} \mathrm{C}$ for one week were weighed $\left(2.5 \mathrm{~g}_{\mathrm{fw}}\right)$ into $50 \mathrm{ml}$ plastic tubes (Sarstedt, non-pyrogenic tube, PP, Germany). The labeled $\left({ }^{15} \mathrm{NH}_{4}\right)_{2} \mathrm{SO}_{4}$ (98 at-\%) soil was incubated for $4 \mathrm{~h}$ and $24 \mathrm{~h}$ at $+15{ }^{\circ} \mathrm{C}$. After incubation, the samples were extracted with $2 \mathrm{M} \mathrm{KCl}$. From these extracts, $\mathrm{NH}_{4}{ }^{+}$was analyzed with a spectrophotometer as described above. Gross nitrification rates were studied similarly as gross $\mathrm{N}$ mineralization, but $\mathrm{K}^{15} \mathrm{NO}_{3}$ (60 at-\%), was added as a label. From these extracts $\mathrm{NO}_{3}{ }^{-}$was analyzed with an ion chromatograph as described above. In both experiments, gross $\mathrm{N} \mathrm{mi-}$ neralization and nitrification, on average $300 \mu \mathrm{l}$ of ${ }^{15} \mathrm{~N}$ labeled solution with a concentration of $0.25 \mu \mathrm{mol}^{-1}$ was added to the soil samples.

The microdiffusion method (Brooks et al., 1989) was applied to determine the isotopic ratio ${ }^{15} \mathrm{~N} /{ }^{14} \mathrm{~N}$ in $\mathrm{NH}_{4}{ }^{+}$and $\mathrm{NO}_{3}{ }^{-}$. For the determination of gross $\mathrm{N}$ mineralization, $0.1 \mathrm{~g}$ of $\mathrm{MgO}$ was added to the flasks and at the same time one acid trap made according to Marushchak et al. (2011) was placed into each flask. The flasks were closed with a septum and screw cap and kept in a heated shaker $\left(+35{ }^{\circ} \mathrm{C}, 150 \mathrm{rpm}\right)$ for 5 days. During the shaking of these alkaline extracts, acidic filter papers trapped the released ammonia $\left(\mathrm{NH}_{3}\right)$. The filter papers from these acid traps were subsequently placed into a desiccator where they were dried in sulphuric acid $\left(\mathrm{H}_{2} \mathrm{SO}_{4}\right)$ atmosphere before transferring them to tin cups for further analyses. The ${ }^{15} \mathrm{~N} /{ }^{14} \mathrm{~N}$ analyses were done at the University of Eastern Finland, Kuopio, using an isotope ratio mass spectrometer (IRMS, Thermo Finnigan Flash DELTA $\mathrm{XP}_{\text {plus }}$, San Jose, CA, USA) coupled to an elemental analyzer (Thermo Finnigan Flash EA 1112 series) and open split interface (Thermo Finnigan Conflow III) (Marushchak et al., 2011).

The microdiffusion method was used also for gross nitrification samples. First, $8-10 \mathrm{ml}$ of extracts, the corresponding volume of $4 \mathrm{M}$ $\mathrm{KCl}$, as well as $0.1 \mathrm{~g}$ of $\mathrm{MgO}$ were added into $150 \mathrm{ml}$ flasks. The flasks were kept open during $4 \mathrm{~h}$ of shaking, after which an acid trap and $0.5 \mathrm{~g}$ of Devarda's alloy were added, and the flasks were closed. Flasks were incubated similarly as the flasks for the gross $\mathrm{N}$ mineralization in a heated shaker. Corrections taking into account the background and different amounts of $\mathrm{N}$ in the samples were made using blanks (same procedure as with samples but without soil extracts or ${ }^{15} \mathrm{~N}$ labeling), and drift correction was applied using standards with known mineral $\mathrm{N}$ concentrations.

\subsection{Nitrous oxide production in soil incubations}

Nitrous oxide production was studied with incubation experiments according to Liimatainen et al. (2014) using field moist soil, with an exception of the Icelandic soils $\left(\mathrm{C}_{\mathrm{I}}\right.$ and $\left.\mathrm{D}_{\mathrm{I}}\right)$. These soils were rather dry and their moisture was adjusted to $60 \%$ of the maximum WHC before incubation experiments. Soil samples were weighed into $550 \mathrm{ml}$ glass 
Table 2

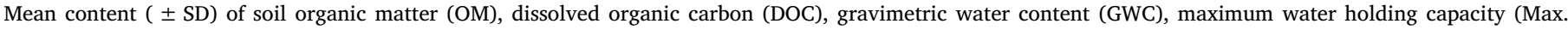

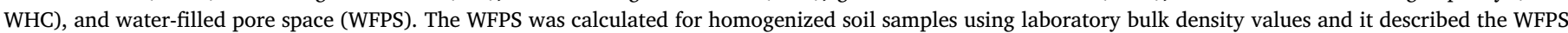

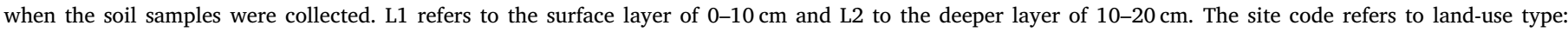
$\mathrm{F}=$ forest, $\mathrm{C}=$ cultivated, $\mathrm{A}=$ afforested field, $\mathrm{D}=$ drained, $\mathrm{B}=$ abandoned field and the subscript defines the site (see Table 1 ).

\begin{tabular}{|c|c|c|c|c|c|c|c|c|c|c|}
\hline \multirow[t]{2}{*}{ Site } & \multicolumn{2}{|l|}{ OM (\%) } & \multicolumn{2}{|c|}{$\mathrm{DOC}\left(\mathrm{mg} \mathrm{C} \mathrm{gdw}^{-1}\right)$} & \multicolumn{2}{|c|}{ GWC (g H2O gdw $\left.{ }^{-1}\right)$} & \multicolumn{2}{|c|}{ Max. WHC (g H2O gdw $\left.{ }^{-1}\right)$} & \multicolumn{2}{|c|}{ WFPS (\%) } \\
\hline & L1 & $\mathrm{L} 2$ & L1 & L2 & L1 & $\mathrm{L} 2$ & L1 & $\mathrm{L} 2$ & L1 & L2 \\
\hline $\mathrm{F}_{\mathrm{S}}$ & $95 \pm 0.1$ & $96 \pm 0.1$ & $0.4 \pm 0.1$ & $0.4 \pm 0.1$ & $2.6 \pm 0.1$ & $3.5 \pm 0.1$ & $5.8 \pm 0.4$ & $5.8 \pm 0.1$ & 31 & 42 \\
\hline $\mathrm{F}_{\mathrm{J}}$ & $90 \pm 0.2$ & $93 \pm 0.1$ & $2.0 \pm 0.3$ & $0.6 \pm 0.1$ & $4.0 \pm 0.1$ & $3.8 \pm 0.0$ & $7.8 \pm 0.0$ & $8.3 \pm 0.1$ & 37 & 37 \\
\hline $\mathrm{C}_{\mathrm{S}}$ & $87 \pm 0.2$ & $86 \pm 0.6$ & $0.7 \pm 0.1$ & $0.5 \pm 0.0$ & $3.8 \pm 0.0$ & $2.7 \pm 0.2$ & $5.0 \pm 0.2$ & $4.4 \pm 0.1$ & 95 & 50 \\
\hline $\mathrm{C}_{\mathrm{I}}$ & $49 \pm 0.7$ & $64 \pm 0.2$ & $0.5 \pm 0.1$ & $0.7 \pm 0.1$ & $1.9 \pm 1.0$ & $1.9 \pm 0.6$ & $5.5 \pm 0.2$ & $5.4 \pm 0.0$ & 25 & 42 \\
\hline $\mathrm{C}_{\mathrm{K}}$ & $50 \pm 1.6$ & $49 \pm 0.5$ & $0.2 \pm 0.0$ & $0.2 \pm 0.0$ & $1.2 \pm 0.0$ & $1.1 \pm 0.0$ & $1.8 \pm 0.0$ & $1.8 \pm 0.0$ & 36 & 36 \\
\hline$A_{L}$ & $82 \pm 0.3$ & $89 \pm 0.0$ & $0.3 \pm 0.0$ & $0.5 \pm 0.1$ & $2.3 \pm 0.0$ & $3.0 \pm 0.1$ & $4.3 \pm 0.1$ & $5.4 \pm 0.0$ & 35 & 38 \\
\hline$A_{R}$ & $60 \pm 1.8$ & $41 \pm 3.9$ & $0.2 \pm 0.0$ & $0.1 \pm 0.0$ & $1.7 \pm 0.0$ & $1.3 \pm 0.1$ & $3.0 \pm 0.1$ & $2.1 \pm 0.1$ & 38 & 36 \\
\hline$A_{G}$ & $91 \pm 0.9$ & $92 \pm 0.9$ & $0.3 \pm 0.1$ & $0.2 \pm 0.0$ & $1.8 \pm 0.0$ & $2.2 \pm 0.1$ & $4.6 \pm 0.1$ & $5.0 \pm 0.6$ & 23 & 37 \\
\hline $\mathrm{D}_{\mathrm{I}}$ & $52 \pm 0.4$ & $57 \pm 0.5$ & $0.4 \pm 0.1$ & $0.3 \pm 0.0$ & $1.1 \pm 0.8$ & $1.6 \pm 0.3$ & $3.1 \pm 0.0$ & $3.9 \pm 0.1$ & 28 & 46 \\
\hline $\mathrm{B}_{\mathrm{A}}$ & $51 \pm 0.3$ & $48 \pm 0.5$ & $0.5 \pm 0.0$ & $0.3 \pm 0.0$ & $2.7 \pm 0.1$ & $2.0 \pm 0.0$ & $3.3 \pm 0.8$ & $2.3 \pm 0.1$ & 92 & 91 \\
\hline $\mathrm{B}_{\mathrm{B}}$ & $37 \pm 1.6$ & $57 \pm 0.9$ & $0.3 \pm 0.0$ & $0.2 \pm 0.0$ & $1.6 \pm 0.0$ & $2.4 \pm 0.2$ & $2.4 \pm 0.2$ & $3.7 \pm 0.0$ & 89 & 46 \\
\hline
\end{tabular}

flasks and incubated in the dark at $+15{ }^{\circ} \mathrm{C}$ for two weeks. During this two-week incubation, gas sampling was performed twice; in the beginning of the experiment, and 2 weeks after starting the experiment, at the end of the incubation. During the measurement of $\mathrm{N}_{2} \mathrm{O}$ production, gas samples were taken 4 times (at 1, 2, 4 and $6 \mathrm{~h}$ time points). To measure the $\mathrm{N}_{2} \mathrm{O}$ production, the flasks were first aerated for $1 \mathrm{~min}$ and then closed with rubber septa and screw cap. Room air was added into the flasks to achieve overpressure, allowing gas sampling. Nitrous oxide sampled from the headspace of the flasks was analyzed via GC (Agilent 6890N Network GC System, Agilent Technologies, USA) equipped with an electron capture detector and using an autosampler (Gilson 222XL, Gilson Company Inc., USA), as described by Maljanen et al. (2014). We use the term ' $\mathrm{N}_{2} \mathrm{O}$ emissions' when referring to $\mathrm{N}_{2} \mathrm{O}$ fluxes measured in situ, and ' $\mathrm{N}_{2} \mathrm{O}$ production' when referring to the $\mathrm{N}_{2} \mathrm{O}$ production rate measured from soil samples in the laboratory. At the end of the incubation, soil $\mathrm{pH}, \mathrm{EC}$ and concentrations of $\mathrm{NO}_{3}{ }^{-}, \mathrm{NO}_{2}{ }^{-}, \mathrm{NH}_{4}{ }^{+}$and DOC were determined as described above, to follow their concentration changes during the 2-week incubation experiment.

\subsection{Statistics}

We used bulk density (BD) values determined in the laboratory (data not shown) for all subsequent calculations and correlation analyses, since in situ BD data (Table 1) was not available for both soil layers. This approach was reasonable since these two values matched well.

Statistical analyses were performed with IBM Statistics software version 21. Kolmogorov-Smirnov and Shapiro-Wilk tests were used to test for normal distribution of data. For soil MBC, $\mathrm{N}_{2} \mathrm{O}$ production rates, isotopic composition of bulk soil $\left(\delta^{15} \mathrm{~N}\right.$ and $\left.\delta^{13} \mathrm{C}\right)$, gross $\mathrm{N}$ mineralization and nitrification, the data was not normally distributed. Therefore, we applied the non-parametric Kruskal-Wallis test for independent samples. Correlations between the $\mathrm{N}_{2} \mathrm{O}$ flux and soil characteristics were calculated using the non-parametric two-tailed Spearman rank bivariate correlation test, separately for the $0-10 \mathrm{~cm}$ soil layer (Table S3) and the $10-20 \mathrm{~cm}$ soil layer (Table S4).

Significances are shown as $* * *$ when $\mathrm{p}<0.001$, ** when $\mathrm{p}<0.01$ and * when $\mathrm{p}<0.05$.

In addition to correlation analyses, we applied principal component analysis (PCA) for this multidimensional data set using packages FactoMineR (Lê et al., 2008) and factoextra (Kassambara and Mundt, 2016) in R version 3.2.2 (R Core Team, 2015). The variables included in the PCA were standardized to unit variance. Variables not complying with assumptions for normal distribution due to obvious occurrence of outliers were log-normalized prior to PCA. Variables with low explanatory power (loadings, Table S5) for the first three components were excluded from the analysis, unless they were presumed to be essential in explaining the variation in $\mathrm{N}_{2} \mathrm{O}$ fluxes. Gross nitrification, gross $\mathrm{N}$ mineralization, $\mathrm{MBC}$ and TP were included only for the PCA of the $10-20 \mathrm{~cm}$ dataset, as these variables were not determined for the $0-10 \mathrm{~cm}$ peat layer. To identify the most important variables explaining the variation in $\mathrm{N}_{2} \mathrm{O}$ production and emissions, we applied linear regression models using stepwise forward selection of predictor variables based on the AIC (Akaike Information Criterion) (R package MASS; Venables and Ripley, 2002), and tested for multicollinearity of predictor variables in the final model by computing variance inflation factors (VIFs). Additionally, we determined measures of relative importance of predictor variables using $\mathrm{R}$ package relaimpo (Grömping, 2006).

\section{Results}

\subsection{Soil physical and chemical properties}

Basic soil physical and chemical properties are shown in Tables 1 and 2. The peat humification varied from 5 to 10 in the von Post scale (Table 1) and WFPS ranged from 23 to $95 \%$ (Table 2). The OM content of peat was between 41 and $96 \%$ among study sites (Table 2). DOC concentrations were rather similar between the study sites

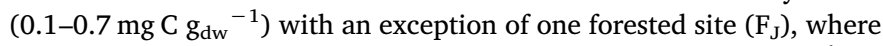

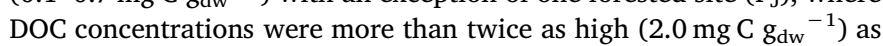
in other sites.

The cultivated $\mathrm{C}_{\mathrm{K}}$ soil displayed the highest and the forest soils $\left(\mathrm{F}_{\mathrm{S}}\right.$, $\mathrm{F}_{\mathrm{J}}$ ) the lowest nutrient contents (Table S2). The highest $\mathrm{P}$ content occurred at site $C_{S}$ and the lowest in the Icelandic $D_{I}$ soil $(10-20 \mathrm{~cm}$; Table $\mathrm{S} 2)$. In the surface layer $(0-10 \mathrm{~cm})$ the $P$ content was lowest in forested peat soils $\left(\mathrm{F}_{\mathrm{S}}, \mathrm{F}_{\mathrm{J}}\right)$ as well as in the abandoned field $\left(\mathrm{B}_{\mathrm{B}}\right)$ and Icelandic site $\left(D_{I}\right)$, the latter being only drained without cultivation or forestry use (ranging from 861 to $956 \mathrm{mg} \mathrm{P} \mathrm{kg}^{-1}$ ). In both soil layers, the concentration of $\mathrm{Cu}$ was highest in the $\mathrm{C}_{\mathrm{S}}$ soil, intermediate in $\mathrm{C}_{\mathrm{I}}, \mathrm{D}_{\mathrm{I}}$ and $\mathrm{C}_{\mathrm{K}}$ soils and low in all other soils (Table S2). The Icelandic soils $\left(\mathrm{C}_{\mathrm{I}}, \mathrm{D}_{\mathrm{I}}\right)$ had a high sodium content compared to other soils.

Soil $\mathrm{pH}$ varied from 3.62 to 5.84 , being similar in both soil layers. The EC varied between 21 and $106 \mu \mathrm{S} \mathrm{cm}^{-1}$ in the surface soil layer and between 36 and $195 \mu \mathrm{S} \mathrm{cm}^{-1}$ in the deeper soil layer of $10-20 \mathrm{~cm}$ with no clear trend relating to land-use type (Table S6). The $\mathrm{NO}_{3}{ }^{-}$content ranged from below detection limit to $49 \mu \mathrm{NO}_{3}-\mathrm{N} \mathrm{g}_{\mathrm{dw}}{ }^{-1}$ whereas the $\mathrm{NH}_{4}{ }^{+}$concentration was between 2 and $108 \mu \mathrm{g} \mathrm{NH}_{4}-\mathrm{N} \mathrm{g}_{\mathrm{dw}}{ }^{-1}$ in both soil layers (Table S6). The site $\mathrm{F}_{\mathrm{S}}$ had the highest $\mathrm{NO}_{2}{ }^{-}$concentration in the soil, $6.92( \pm 1.98) \mu \mathrm{g} \mathrm{NO} \mathrm{NO}_{2}-\mathrm{N} \mathrm{g}_{\mathrm{dw}}{ }^{-1}$ in the surface soil and 5.24 $( \pm 0.28) \mu \mathrm{g} \mathrm{g}^{-1}$ in the deeper soil layer, respectively. In other sites soil $\mathrm{NO}_{2}{ }^{-}$concentrations were negligible (data not shown). 


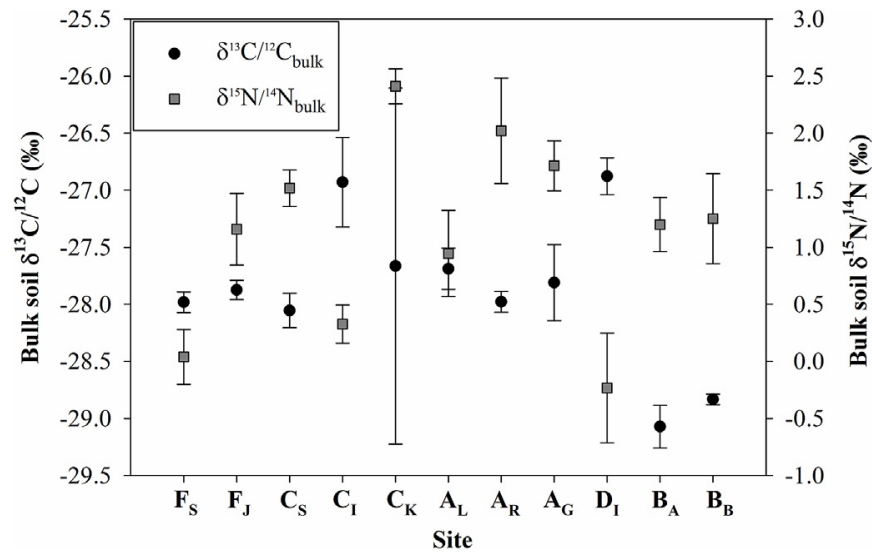

Fig. 1. Isotopic composition ( \pm SD) of $N$ and $C$ for the peat layer of $0-20 \mathrm{~cm}$ of the sites. The left y-axis shows the bulk soil $\delta^{13} \mathrm{C}$ (black circles) and the right $\mathrm{y}$ axis the bulk soil $\delta^{15} \mathrm{~N}$ (grey squares). $\mathrm{n}=4$ except for BB where $\mathrm{n}=3$.

The $\delta^{15} \mathrm{~N}$ and $\delta^{13} \mathrm{C}$ values in bulk peat were similar in both soil layers $(0-10 \mathrm{~cm}$ and $10-20 \mathrm{~cm})$. Therefore, the mean isotopic compositions were calculated for the two layers. The peat at the cultivated $\mathrm{C}_{\mathrm{K}}$ site was the most enriched in ${ }^{15} \mathrm{~N}$ whereas in the forest site $\mathrm{F}_{\mathrm{S}}$ and Icelandic sites $C_{I}$ and $D_{I}$ the soils were the most depleted (Fig. 1). In contrast, the $C_{I}$ and $D_{I}$ soils were the most enriched in ${ }^{13} \mathrm{C}$ and the abandoned fields $\mathrm{B}_{\mathrm{A}}$ and $\mathrm{B}_{\mathrm{B}}$ soils the most depleted in ${ }^{13} \mathrm{C}$ (Fig. 1). The isotopic $\delta^{15} \mathrm{~N}$ value of the soil correlated positively with the degree of peat humification. This trend was stronger in the in the deeper $(p<0.01)$ than in the surface peat layer $(p<0.05)$.

\subsection{Microbial biomass $C$}

Microbial biomass $C$ (MBC) was highest in the cultivated $C_{S}$ soil, 1945 ( \pm 346) $\mu \mathrm{g} \mathrm{C} \mathrm{g}_{\mathrm{dw}}{ }^{-1}$ (Fig. 2). Clearly the lowest MBC among all sites occurred in the $A_{R}$ and $D_{I}$ soils, $182( \pm 34)$ and $329( \pm 98) \mu g \mathrm{C}$ $\mathrm{gd}_{\mathrm{w}}{ }^{-1}$, respectively, especially compared to the $\mathrm{C}_{\mathrm{S}}$ site $(p<0.001)$. All other sites displayed a medium MBC ranging from 454 to $754 \mu \mathrm{g} \mathrm{C}$ $\mathrm{gd}_{\mathrm{w}}{ }^{-1}$. The MBC of the soil correlated positively with WHC of the sites $(p<0.05)$ (Table S4).

\subsection{Gross $N$ mineralization and gross nitrification rates}

The $A_{L}$ and $C_{I}$ soils (Fig. 3) displayed the highest gross $\mathrm{N}$ mineralization rates, $\left(>7 \mathrm{mg} \mathrm{N} \mathrm{kg}_{\mathrm{dw}}{ }^{-1} \mathrm{~d}^{-1}\right.$ ), and the soils $B_{\mathrm{A}}$ and $A_{\mathrm{R}}$ the

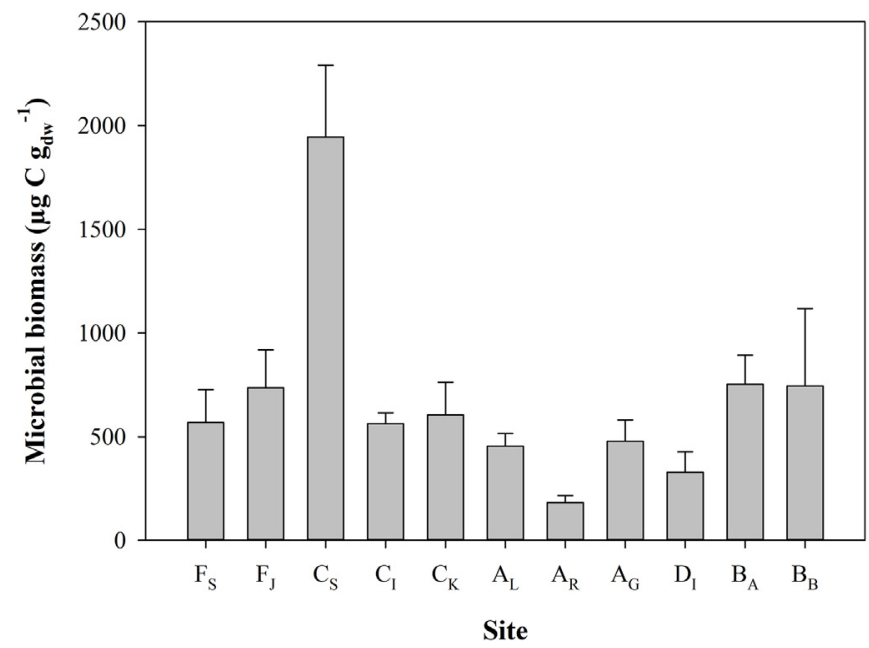

Fig. 2. Microbial biomass $C$ for the sites ( $\mu$ g microbial $C g_{d w}{ }^{-1} \pm S D, n=5$ ) determined for $10-20 \mathrm{~cm}$ soil layer.

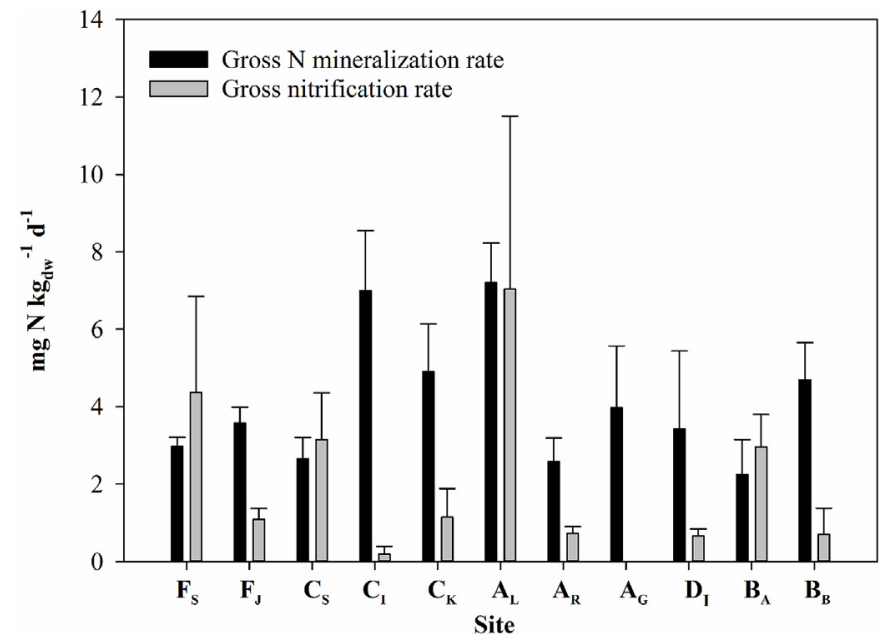

Fig. 3. Gross $\mathrm{N}$ mineralization and gross nitrification rates $\left(\mathrm{mg} \mathrm{N} \mathrm{kg} \mathrm{dw}^{-1}\right.$ $\mathrm{d}^{-1} \pm \mathrm{SD}$ ) determined for $10-20 \mathrm{~cm}$ soil layer. ${ }^{*}$ Gross nitrification result is missing from the $\mathrm{A}_{\mathrm{G}}$ soil.

lowest ( $<3 \mathrm{mg} \mathrm{N} \mathrm{kg} \mathrm{dw}^{-1} \mathrm{~d}^{-1}$ ). The gross nitrification rate was highest in the $A_{L}$ and $F_{S}$ soils, albeit with high variation (Fig. 3), whereas the lowest gross nitrification rate occurred in the $C_{I}$ soil. The gross nitrification result for site $A_{G}$ was excluded from this study due to a negative gross rate. In the correlation and PCA analyses we used gross nitrification data from Holz et al. (2015) for the $A_{G}$ site.

\subsection{Nitrous oxide emissions in situ and production in laboratory experiments}

Published $\mathrm{N}_{2} \mathrm{O}$ flux data for our sites showed the lowest $\mathrm{N}_{2} \mathrm{O}$ fluxes from Icelandic soils $\left(\mathrm{C}_{\mathrm{I}}, \mathrm{D}_{\mathrm{I}}\right)$, ranging between 0.03 and $0.04 \mathrm{~g} \mathrm{~N} \mathrm{~m}^{-2}$ $\mathrm{y}^{-1}$, and the highest from $\mathrm{C}_{\mathrm{S}}$ and $\mathrm{A}_{\mathrm{L}}$ soils, 2.38 and $2.14 \mathrm{~g} \mathrm{~N} \mathrm{~m}^{-2} \mathrm{y}^{-1}$, respectively (Table 1, Fig. 4). The $\mathrm{N}_{2} \mathrm{O}$ emissions correlated positively with the soil $\mathrm{NO}_{3}{ }^{-}$concentration $(p<0.01$, Table S4) in the $10-20 \mathrm{~cm}$ soil layer measured after 2 weeks of incubation, as well as with gross nitrification ( $\mathrm{p}<0.01$, Table S4). It has to be noted that gross nitrification was determined only for the deeper soil layer. The sites displaying the highest in situ $\mathrm{N}_{2} \mathrm{O}$ emissions had also the highest $\mathrm{P}$ content in the $10-20 \mathrm{~cm}$ soil layer $(p<0.05)$ (Fig. 4, Tables 1 and S4).

In the beginning of the incubation experiments $(0 \mathrm{wk})$ the $\mathrm{N}_{2} \mathrm{O}$ production in the $0-10 \mathrm{~cm}$ layer was highest in the $\mathrm{C}_{\mathrm{S}}$ soil, amounting to $46.5( \pm 17.6) \mathrm{ng} \mathrm{N} \mathrm{N}_{2} \mathrm{O} \mathrm{g} \mathrm{dw}^{-1} \mathrm{~h}^{-1}$. In all other soils, the $\mathrm{N}_{2} \mathrm{O}$

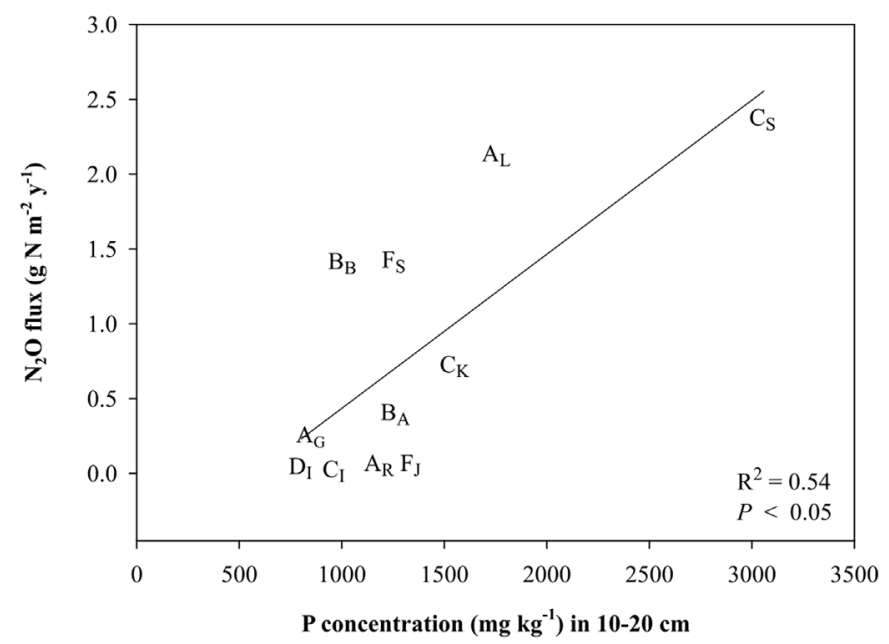

Fig. 4. Correlation between $\mathrm{N}_{2} \mathrm{O}$ emissions $\left(\mathrm{g} \mathrm{N} \mathrm{m}^{-2} \mathrm{y}^{-1}\right)$ in situ and the content of total $\mathrm{P}\left(\mathrm{mg} \mathrm{kg}^{-1}\right)$ in soil at the depth of $10-20 \mathrm{~cm}$. 

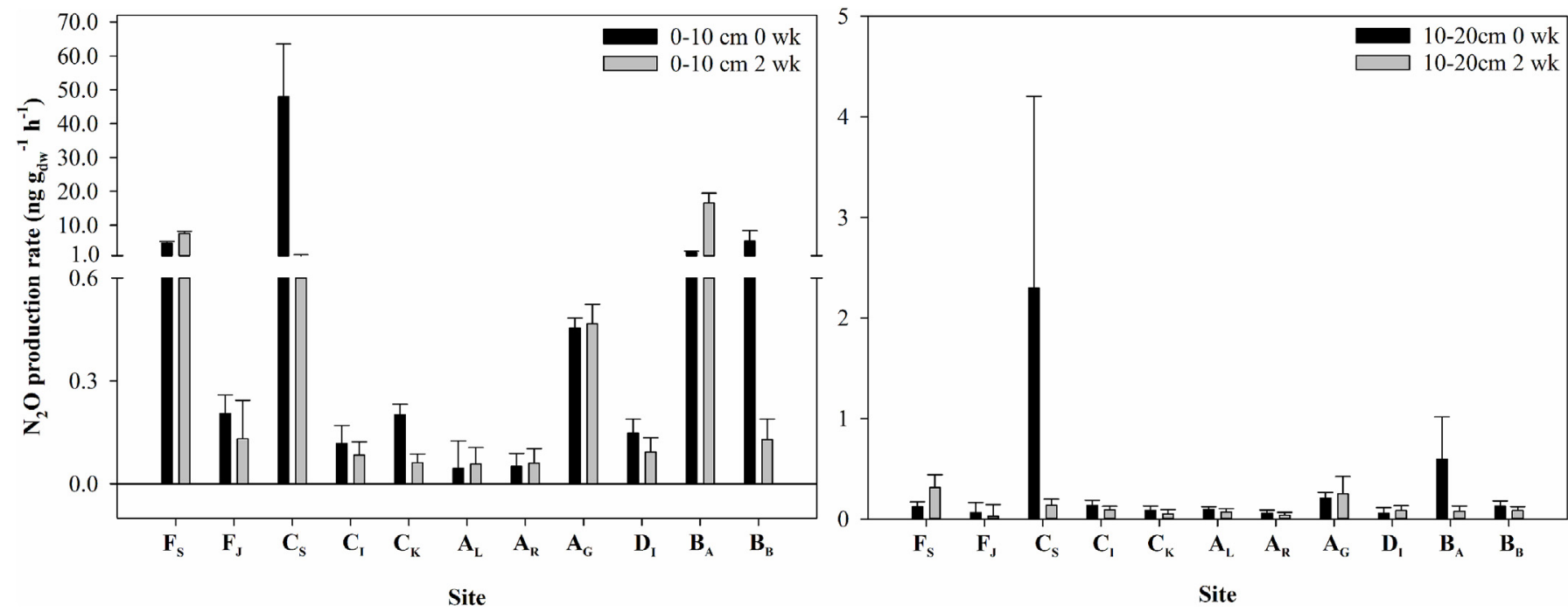

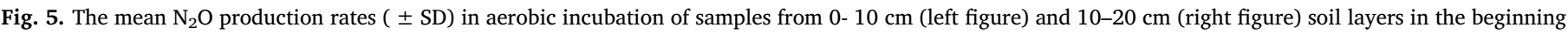
( 0 wk, black bars) and after the 2 week incubation ( $2 \mathrm{wk}$, grey bars) at $+15{ }^{\circ} \mathrm{C}$.

production was $10 \%$ or less of that in the $C_{S}$ soil (Fig. 5), and significantly lower $(p<0.001)$ especially in the $A_{L}$ and $A_{R}$ soils, where $\mathrm{N}_{2} \mathrm{O}$ production was only $0.05 \mathrm{ng} \mathrm{N_{2 }} \mathrm{O} \mathrm{g} \mathrm{dw}^{-1} \mathrm{~h}^{-1}$. After a 2-week incubation, the $\mathrm{N}_{2} \mathrm{O}$ production in the $\mathrm{C}_{\mathrm{S}}$ soil decreased and the highest $\mathrm{N}_{2} \mathrm{O}$ production took place in the $\mathrm{F}_{\mathrm{S}}$ and $\mathrm{B}_{\mathrm{A}}$ soils. The $\mathrm{N}_{2} \mathrm{O}$ production was higher in the $0-10 \mathrm{~cm}$ soil layer than in the $10-20 \mathrm{~cm}$ layer. At the start of the incubation the $\mathrm{C}_{\mathrm{S}}$ soil showed higher $\mathrm{N}_{2} \mathrm{O}$ production rates than most of the other soils also in the $10-20 \mathrm{~cm}$ layer (Fig. 5). Similar to the surface soil layer, the $\mathrm{N}_{2} \mathrm{O}$ production rate in the deeper soil layer was rather similar between all sites after 2 weeks of incubation.

After determining the $\mathrm{N}_{2} \mathrm{O}$ production rate in the aerobic incubation experiments for the two-week incubation at $+15{ }^{\circ} \mathrm{C}$, soil samples were extracted for $\mathrm{NO}_{3}{ }^{-}, \mathrm{NO}_{2}{ }^{-}, \mathrm{NH}_{4}{ }^{+}, \mathrm{pH}$ and $\mathrm{EC}$ analyses. The $\mathrm{pH}$ measured after 2 weeks of incubation (data not shown) did not significantly differ from the $\mathrm{pH}$ measured at the beginning of the incubation (Table S6). The $F_{S}$ and $A_{G}$ soils had the highest $E C$, amounting to $>190$ $\mu \mathrm{S} \mathrm{cm}^{-3}$. Generally, EC increased in all soils during the incubation, except in $F_{J}$ where EC showed constant values (Table S6). Nitrate concentrations also increased during the incubation, especially in $F_{S}$, $\mathrm{C}_{S}, \mathrm{~A}_{\mathrm{G}}$ and $\mathrm{A}_{\mathrm{L}}$ soils. Ammonium concentrations increased especially in the $A_{G}, F_{S}$ and $F_{J}$ soils and decreased in the $B_{A}, C_{S}$ and $C_{K}$ soils (Table S6). After incubation, the $\mathrm{NO}_{2}{ }^{-}$concentration in all soils were negligible (data not shown).

\subsection{Correlation of $\mathrm{N}_{2} \mathrm{O}$ production and emissions with soil characteristics and nitrogen turnover processes}

Six components were extracted in the PCA, explaining in both layers together $91 \%$ of the total variance, with the first three components accounting for $69-70 \%$ of the variance (Table S7).

The component 1 illustrated especially the nutrient status of the sites (Table $\mathrm{S} 2$ ); forested sites $\left(\mathrm{F}_{\mathrm{S}}, \mathrm{F}_{\mathrm{J}}\right)$ with lowest nutrient status in general were clearly separately from the cultivated site $\mathrm{C}_{\mathrm{K}}$ with highest nutrient status (Fig. 6). In the PCA, the sites with similar land-use formed clusters: in both soil layers, $(0-10 \mathrm{~cm}$ and $10-20 \mathrm{~cm})$ the forest sites $\left(F_{S}, F_{J}\right)$, the afforested sites $\left(A_{L}, A_{R}, A_{G}\right)$ and the abandoned, formerly cultivated $\left(\mathrm{B}_{\mathrm{A}}, \mathrm{B}_{\mathrm{B}}\right)$ sites formed an own cluster. An exception from this clustering were the cultivated sites $\left(\mathrm{C}_{\mathrm{K}}, \mathrm{C}_{\mathrm{S}}, \mathrm{C}_{\mathrm{I}}\right)$, showing large variability. Also, forested sites $\left(\mathrm{F}_{\mathrm{S}}, \mathrm{F}_{\mathrm{J}}\right)$ were closer to afforested fields $\left(A_{L}, A_{R}, A_{G}\right)$ than actively cultivated fields $\left(C_{K}, C_{S}, C_{I}\right)$ or abandoned fields $\left(B_{A}, B_{B}\right)$. The Icelandic sites $C_{I}$ (cultivated hay field) and $D_{I}$ (drained) formed a separate cluster: besides having the lowest $\mathrm{N}_{2} \mathrm{O}$ fluxes, these sites also differed from the remaining sites in their soil chemical properties caused by volcanic ash deposition.

The results of the PCA (Fig. 6) indicate that in the surface soil layer the $\mathrm{N}_{2} \mathrm{O}$ production and fluxes interact especially with the $\delta^{15} \mathrm{~N}$ of the bulk soil, the $\mathrm{C} / \mathrm{N}$ ratio, WFPS, degree of humification $(H)$, bulk density (BD) and the concentration of certain metals and nutrients $(\mathrm{P}, \mathrm{Cd}, \mathrm{B}, \mathrm{K})$. Step-wise linear regression (Table 3 ) identified the $\mathrm{P}$ concentration as the key variable to the $\mathrm{N}_{2} \mathrm{O}$ flux from the surface layer (model strength $46 \%$, Table 3). Nitrous oxide production in the surface soil on the other hand was best explained by WFPS and the $\mathrm{Cu}$ concentration, in addition to the OM content and the $\mathrm{C} / \mathrm{N}$ ratio (model strength $98 \%$, Table 3 ).

For the deeper soil layer PCA showed that $\mathrm{N}_{2} \mathrm{O}$ flux and production interrelate with $\delta^{15} \mathrm{~N}$ of bulk soil, degree of humification $(H)$ and some metals and nutrients $(\mathrm{P}, \mathrm{Cd}, \mathrm{Cu})$, but also with $\mathrm{MBC}, \mathrm{NH}_{4}{ }^{+}$concentration and gross nitrification (Fig. 6B). According to the step-wise linear regression (Table 3 ), gross nitrification and $\mathrm{P}$ concentration were the most important factors explaining the $\mathrm{N}_{2} \mathrm{O}$ flux (model strength $75 \%$ ), whereas $\mathrm{N}_{2} \mathrm{O}$ production was best explained by $\mathrm{MBC}$, soil $\mathrm{Cu}$ concentration, gross $\mathrm{N}$ mineralization and gross nitrification (model strength $96 \%$ ).

\section{Discussion}

4.1. Links between nitrate availability, soil water content and nitrous oxide production and emissions

In contrast to nutrient poor peatland forests, $\mathrm{N}_{2} \mathrm{O}$ emissions in nutrient rich boreal peatland forests can be high (Martikainen et al., 1993). In peatland forests, $\mathrm{N}_{2} \mathrm{O}$ emissions depend on the peat $\mathrm{C} / \mathrm{N}$ ratio, high emissions being expected in $\mathrm{N}$ rich soils with $\mathrm{C} / \mathrm{N}<25-30$ (Klemedtsson et al., 2005). A low soil $\mathrm{C} / \mathrm{N}$ ratio supports net $\mathrm{N}$ mineralization and associated nitrification, increasing the availability of $\mathrm{NH}_{4}{ }^{+}, \mathrm{NO}_{3}{ }^{-}$and $\mathrm{NO}_{2}{ }^{-}$in the peat profile, the two latter ions being the key substrates for denitrification, the most potential process for $\mathrm{N}_{2} \mathrm{O}$ production in soils (Butterbach-Bahl et al., 2013). In agricultural soils regularly receiving $\mathrm{N}$ fertilizers, nitrification and denitrification are less dependent on $\mathrm{N}$ mineralization than in peatland forest soils that receive extra $\mathrm{N}$ almost exclusively through atmospheric deposition. While studies conducted in boreal peatland forests do not support this hypothesis of high $\mathrm{N}_{2} \mathrm{O}$ emissions at optimum $\mathrm{C} / \mathrm{N}$ ratio, peatland forests with a cultivation history do exhibit high $\mathrm{N}_{2} \mathrm{O}$ emissions within this optimum $\mathrm{C} / \mathrm{N}$ range (Ojanen et al., 2010). Thus, across the variety of land-use options, peatlands display a high variability in $\mathrm{N}_{2} \mathrm{O}$ emissions within this optimum C/N ratio of 15-30 (Leppelt et al., 2014; Maljanen et al., 

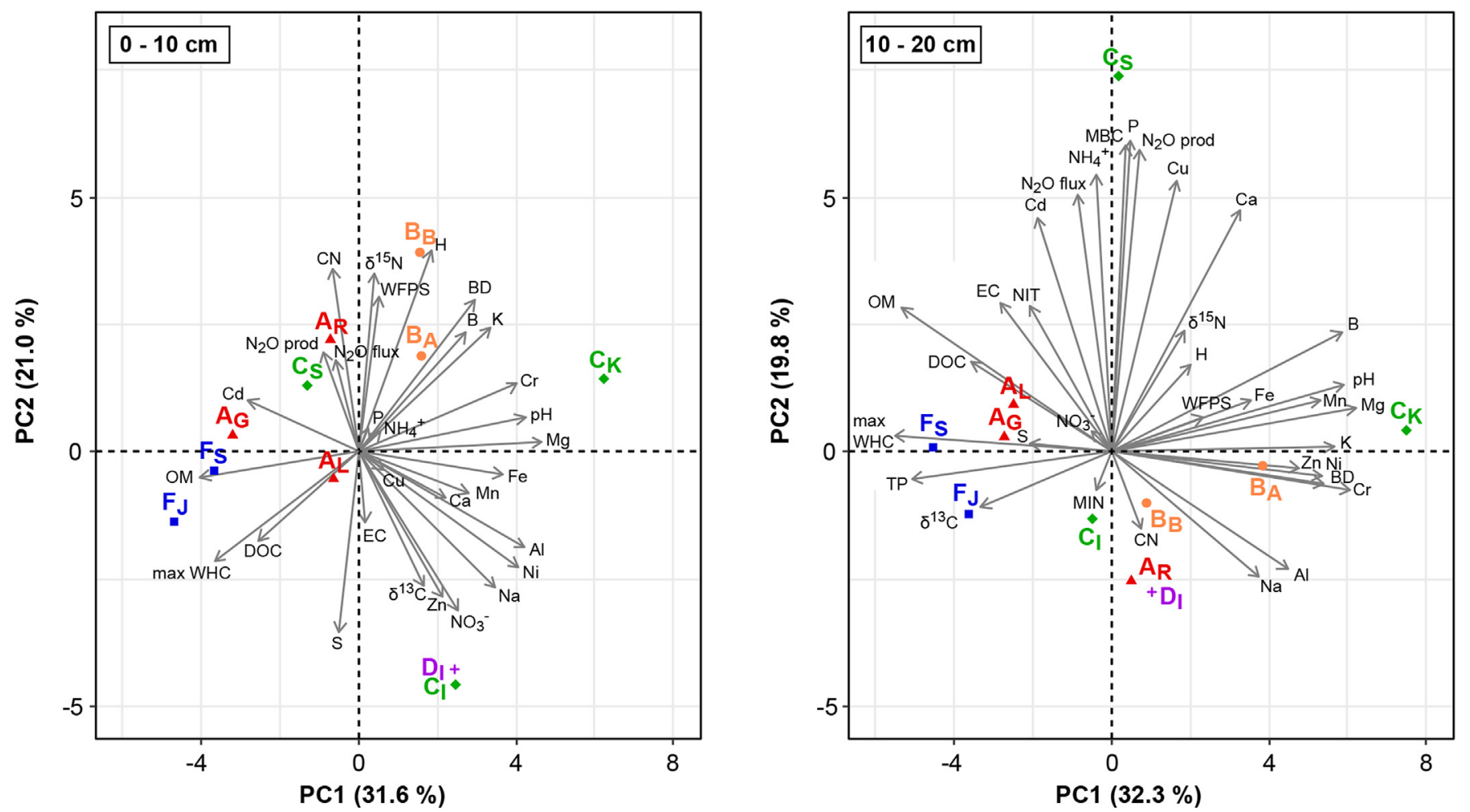

\begin{tabular}{lll|}
\hline Abandoned field & Cultivated field & + Drained, not used \\
- Afforested field & Forest & for forestry or agriculture \\
\hline
\end{tabular}

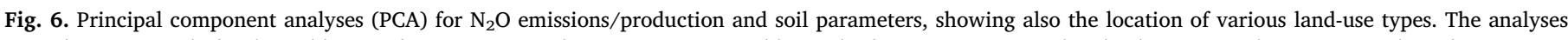

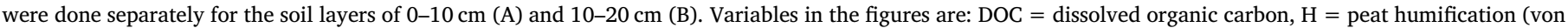

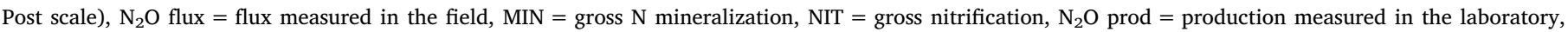

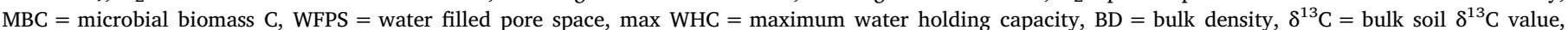

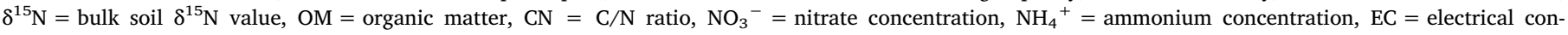

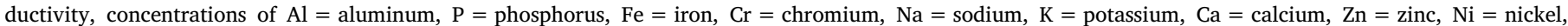

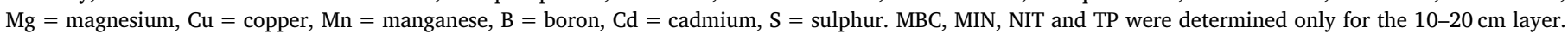

Table 3

Step-wise linear regression models. $\mathrm{N}_{2} \mathrm{O}$ flux refers to field measurements and $\mathrm{N}_{2} \mathrm{O}$ production to laboratory experiments. Predictor variables in the table refer to: $\mathrm{P}=$ phosphorus concentration in bulk soil $\left(\mathrm{mg} \mathrm{kg}^{-1}\right), \mathrm{Cu}=$ copper concentration in bulk soil $\left(\mathrm{mg} \mathrm{kg}^{-1}\right)$, WFPS = water filled pore space (\%), $\mathrm{OM}=$ organic matter content $(\%), \mathrm{C} / \mathrm{N}=$ carbon to nitrogen ratio, NIT = gross nitrification ( $\mathrm{mg} \mathrm{N} \mathrm{kgdw}^{-1} \mathrm{~d}^{-1}$ ), MBC = microbial biomass $\mathrm{C}\left(\mu \mathrm{g} \mathrm{C} \mathrm{g} \mathrm{dw}^{-1}\right)$, $\mathrm{MIN}=$ gross $\mathrm{N}$ mineralization $\left(\mathrm{mg} \mathrm{N} \mathrm{kg}_{\mathrm{dw}}{ }^{-1} \mathrm{~d}^{-1}\right)$. MBC, NIT and MIN were not determined for the $0-10 \mathrm{~cm}$ soil layer and therefore not included in the regression analysis for the surface layer. $* * *$ Significant at the level $\mathrm{p}<0.001$, $* * \mathrm{p}<0.01, * \mathrm{p}<0.05$.

\begin{tabular}{|c|c|c|c|c|c|c|}
\hline $\begin{array}{l}\text { Soil } \\
\text { depth } \\
(\mathrm{cm})\end{array}$ & $\begin{array}{l}\text { Response } \\
\text { variable }\end{array}$ & $\begin{array}{l}\text { Predictor } \\
\text { variables }\end{array}$ & $\begin{array}{l}\text { Relative } \\
\text { importance } \\
\text { of the } \\
\text { variable }\end{array}$ & $P$ value & & $\begin{array}{l}\text { Proportion of } \\
\text { variance } \\
\text { explained by } \\
\text { model (\%) }\end{array}$ \\
\hline \multirow[t]{5}{*}{$0-10$} & $\mathrm{~N}_{2} \mathrm{O}$ flux & $\mathrm{P}$ & - & 0.0211 & * & 46.35 \\
\hline & $\mathrm{N}_{2} \mathrm{O}$ & $\mathrm{Cu}$ & 0.5947 & 0.0008 & $* * *$ & 97.75 \\
\hline & production & WFPS & 0.2483 & 0.0033 & $* * *$ & \\
\hline & & $\mathrm{OM}$ & 0.0907 & 0.0058 & $* *$ & \\
\hline & & $\mathrm{C} / \mathrm{N}$ & 0.0438 & 0.0912 & & \\
\hline \multirow[t]{6}{*}{$10-20$} & $\mathrm{~N}_{2} \mathrm{O}$ flux & $\mathrm{P}$ & 0.3836 & 0.0285 & $*$ & 74.93 \\
\hline & & NIT & 0.3657 & 0.0338 & * & \\
\hline & $\mathrm{N}_{2} \mathrm{O}$ & MBC & 0.4673 & 0.0161 & * & 95.58 \\
\hline & production & $\mathrm{Cu}$ & 0.3949 & 0.0349 & * & \\
\hline & & MIN & 0.0683 & 0.0763 & & \\
\hline & & NIT & 0.0253 & 0.1925 & & \\
\hline
\end{tabular}

2010a). Consequently, other environmental parameters besides the $\mathrm{C} / \mathrm{N}$ ratio have to be considered when attempting to predict $\mathrm{N}_{2} \mathrm{O}$ emission rates from drained peatlands.

In our study, the availability of $\mathrm{NO}_{3}{ }^{-}$was a predictor for $\mathrm{N}_{2} \mathrm{O}$ emissions which correlated positively with the soil $\mathrm{NO}_{3}{ }^{-}$concentration $(p<0.01$, Table S4) measured after 2 weeks of incubation, showing net nitrification. Net nitrification also correlated positively with $\mathrm{N}_{2} \mathrm{O}$ emissions from drained peat soil under in situ conditions (Regina et al., 1998a). As a result of $\mathrm{NO}_{3}{ }^{-}$production and consumption (including plant $\mathrm{N}$ uptake), the initial $\mathrm{NO}_{3}{ }^{-}$concentration poorly describes $\mathrm{NO}_{3}{ }^{-}$ production. Also, net nitrification rates obtained in soil incubation experiments are not an exact measure of $\mathrm{NO}_{3}{ }^{-}$production either (Hart et al., 1994), because such experiments do not show immobilization of $\mathrm{NH}_{4}{ }^{+}$and $\mathrm{NO}_{3}{ }^{-}$. By using a ${ }^{15} \mathrm{~N}$ technique, we determined gross $\mathrm{N}$ mineralization and nitrification rates which were in the range reported for mineral and peatland forest soils (Stark and Hart, 1997; Verchot et al., 2001; Westbrook and Devito, 2004) and for a mineral arable soil (Luxhøi et al., 2004). In our study, the initial $\mathrm{NO}_{3}{ }^{-}$concentration did not correlate with $\mathrm{N}_{2} \mathrm{O}$ emissions, as expected, but gross nitrification rates did correlate positively with the $\mathrm{N}_{2} \mathrm{O}$ emissions $(10-20 \mathrm{~cm}$; Table 3, Table S4) further stressing the importance of nitrification and $\mathrm{NO}_{3}{ }^{-}$production in promoting $\mathrm{N}_{2} \mathrm{O}$ emissions. While we did not determine gross nitrification rates for the surface soil layer, a similar correlation between gross nitrification rates and $\mathrm{N}_{2} \mathrm{O}$ emissions can be expected also in the surface soil. In a study by Regina et al. (1996), focusing on both nutrient poor and nutrient rich drained boreal 
peatlands, $\mathrm{N}_{2} \mathrm{O}$ emissions correlated positively with the number of nitrifiers and the nitrification potential. Our results thus suggest that, surprisingly, a lack of $\mathrm{NO}_{3}{ }^{-}$can limit $\mathrm{N}_{2} \mathrm{O}$ production even in peat soils where, based on their low $\mathrm{C} / \mathrm{N}$ ratio, we would expect a sufficient $\mathrm{NO}_{3}{ }^{-}$ availability to allow high $\mathrm{N}_{2} \mathrm{O}$ production.

During the nitrification process, ${ }^{15} \mathrm{~N}$-depleted $\mathrm{NO}_{3}{ }^{-}$is produced and loss of this $\mathrm{NO}_{3}{ }^{-}$via leaching and denitrification causes ${ }^{15} \mathrm{~N}$-enrichment in the soil (Callesen et al., 2013; Högberg and Johansson, 1993). In our study, ${ }^{15} \mathrm{~N}$ enrichment of the bulk soil increased with increasing peat humification (Tables S3 and S4, Fig. 1) that is known to increase with soil OM mineralization. A higher degree of humification thus reflects higher cumulative $\mathrm{N}$ mineralization and $\mathrm{NO}_{3}{ }^{-}$production with time. More humified soils have also lost higher amounts of ${ }^{15} \mathrm{~N}$ depleted $\mathrm{NO}_{3}{ }^{-}$leading to ${ }^{15} \mathrm{~N}$ enrichment in the residual organic matter.

The $\mathrm{C} / \mathrm{N}$ ratio of the peat is linked to the degree of humification (Kasimir-Klemedtsson et al., 1997; Klemedtsson et al., 2005), and more decomposed peat was shown to emit larger rates of $\mathrm{N}_{2} \mathrm{O}$ (Regina et al., 2004). In our study, the PCA (Fig. 6) but not the regression models indicated that there was a link between the degree of humification and the $\mathrm{N}_{2} \mathrm{O}$ flux and production in both soil layers. The degree of peat humification alone is not sufficient in explaining the variation in $\mathrm{N}_{2} \mathrm{O}$ emissions, as $\mathrm{N}_{2} \mathrm{O}$ production is, besides other peat physical and chemical characteristics, regulated by the presence and activity of denitrifiers. The growth and activity of heterotrophic microbes including denitrifiers are regulated by the availability of substrates, especially organic C. The DOC pool contains easily available organic compounds for microbial use and in our study, DOC concentrations in the upper soil layer correlated positively with $\mathrm{N}_{2} \mathrm{O}$ production $(p<0.05)$ after 2 weeks of incubation.

In addition to a sufficient supply of mineral $\mathrm{N}$ the soil water content needs to fall within a certain range to support $\mathrm{N}_{2} \mathrm{O}$ production. If the soil is water-saturated, $\mathrm{N}_{2} \mathrm{O}$ emissions from peat soils without external $\mathrm{N}$ input are minor because anaerobic conditions limit mineralization and nitrification (Martikainen et al., 1993). Nitrous oxide production is also limited if the soil water content is too low because microbial activities and substrate diffusion are restricted under low soil water content conditions (Stark and Firestone, 1995; Bateman and Baggs, 2005). In Finland, afforested former arable land on mineral soils is usually well drained and aerated whereas on organic soils the drainage system may not work adequately and often tree growth on organic soils is limited due to the bad aeration (Wall and Heiskanen, 2009). The optimum WFPS for $\mathrm{N}_{2} \mathrm{O}$ production in boreal peat soils varies from 50 to $90 \%$ (Regina et al., 1998a). In our study the WFPS ranged from 23 to $95 \%$. According to the PCA, WFPS was closely connected with $\mathrm{N}_{2} \mathrm{O}$ flux and production, especially in the $0-10 \mathrm{~cm}$ layer (Fig. 6A). This suggests that in some cases the upper soil layer is too dry for optimum $\mathrm{N}_{2} \mathrm{O}$ production, as denitrification is limited by too high $\mathrm{O}_{2}$ content. It is logical that the initial $\mathrm{NO}_{3}{ }^{-}$content in the surface layer displayed a reverse relationship with WFPS (Table S3): the $\mathrm{NO}_{3}{ }^{-}$content increased with decreasing WFPS indicating that nitrification is on-going, while denitrification is limited, leading to an accumulation of $\mathrm{NO}_{3}{ }^{-}$. In the correlation analyses, however, none of the moisture parameters correlated with $\mathrm{N}_{2} \mathrm{O}$ production (Tables S3 and S4), likely due to interlinkages between moisture and other variables, but regression models showed that in the surface soil layer WFPS is one of the key parameters to explain $\mathrm{N}_{2} \mathrm{O}$ production (Table 3). Results obtained in the Mt. Kilimanjaro region, Tanzania (Gütlein et al., 2017) demonstrate the importance of both $\mathrm{C} / \mathrm{N}$ ratio and soil water content on $\mathrm{N}_{2} \mathrm{O}$ fluxes also in tropical ecosystems. There, similar to our study, regression analysis revealed that besides the $\mathrm{C} / \mathrm{N}$ ratio and soil water content also the soil $\mathrm{N}$ content controlled $\mathrm{N}_{2} \mathrm{O}$ emissions.

\subsection{Soil chemistry and nitrous oxide emissions and production}

Agreeing with results obtained by Regina et al. (1996), our study suggests that, besides mineral $\mathrm{N}$ availability, soil $\mathrm{P}$ concentration plays an important role in regulating $\mathrm{N}_{2} \mathrm{O}$ production and emissions in managed boreal peat soils (Figs. 4 and 6, Table 3, Table S4). Soil $\mathrm{P}$ content was low in the forested peat soils (Tables 1 and S2) and a low P content is known to limit tree growth on boreal drained peatlands (e.g. Moilanen et al., 2015). Thus, there is a large competition between plants and microbes for $\mathrm{P}$ in peatland forest soils, where also microbial activities and growth could suffer from a lack of P. The PCA showed that MBC (determined in $10-20 \mathrm{~cm}$ ) was connected with the P concentration. A study conducted on peat soils by Amador and Jones (1993) showed that microbial respiration in peat soils can be limited by the amount of total P. As a result of fertilization, agricultural soils displayed higher amounts of $\mathrm{P}$ (Tables 1 and S2) than forest soils, and $\mathrm{P}$ is less likely to limit microbial processes in agricultural soils. A higher $\mathrm{P}$ content could promote either nitrification, denitrification, or both of these processes, leading to increased $\mathrm{N}_{2} \mathrm{O}$ production and emissions (Mehnaz and Dijkstra, 2016). The direct effect of soil P concentration on $\mathrm{N}_{2} \mathrm{O}$ production remains unclear, but $\mathrm{P}$ input was shown to stimulate microbial activity (Wang et al., 2014) and to enhance $\mathrm{N}_{2} \mathrm{O}$ emissions in $\mathrm{N}$ fertilized mineral soils (Mehnaz and Dijkstra, 2016; Ullah et al., 2016). Importantly, these three studies used mineral soils with external $\mathrm{P}$ input in the laboratory, whereas our study shows the direct link between $\mathrm{N}_{2} \mathrm{O}$ production and in situ $\mathrm{P}$ variability among managed peatland sites. Our study thus highlights the need for in-depth studies on the linkage between the $\mathrm{N}$ and $\mathrm{P}$ cycle in northern peatlands, in order to improve our understanding of $\mathrm{N}_{2} \mathrm{O}$ emission from these ecosystems.

In addition to the $\mathrm{P}$ concentration, the soil $\mathrm{Cu}$ content seemed to have an important role in $\mathrm{N}_{2} \mathrm{O}$ production. Copper is an essential component in ammonium monooxidase (AMO) of ammonium oxidizers (Gilch et al., 2009), and in nitrous oxide reductase (NOS) of denitrifiers (Richardson et al., 2009). Therefore, a low availability of $\mathrm{Cu}$ in soil could limit denitrification processes (Richardson et al., 2009). The NOS is the last enzyme in the denitrification catalyzing reduction of $\mathrm{N}_{2} \mathrm{O}$ to $\mathrm{N}_{2}$. If there is lack of $\mathrm{Cu}$, the NOS activity can be limited, thereby enhancing $\mathrm{N}_{2} \mathrm{O}$ release from denitrification by inhibiting the last step of denitrification (reduction of $\mathrm{N}_{2} \mathrm{O}$ to $\mathrm{N}_{2}$ ). Ensuring a sufficient $\mathrm{Cu}$ availability is suggested to be one $\mathrm{N}_{2} \mathrm{O}$ mitigation option in agricultural soils (Thompson et al., 2012) as well as in waste water treatments (Desloover et al., 2012). Interestingly, the effect of Cu availability on $\mathrm{N}_{2} \mathrm{O}$ emissions in our study was vice versa, i.e. with higher $\mathrm{Cu}$ availability the $\mathrm{N}_{2} \mathrm{O}$ emissions were higher. According to the PCA, the soil $\mathrm{Cu}$ concentration was linked to $\mathrm{N}_{2} \mathrm{O}$ production and fluxes in both soil layers, but especially in the deeper one (Fig. 6A and B). The fact that $\mathrm{N}_{2} \mathrm{O}$ emissions were higher with higher $\mathrm{Cu}$ concentration indicates that, unexpectedly, denitrification was not the main process for $\mathrm{N}_{2} \mathrm{O}$ production at our sites. In correlation analyses the $\mathrm{Cu}$ content did not correlate with either $\mathrm{N}_{2} \mathrm{O}$ production or fluxes, which is understandable since in correlation analyses only two variables are considered at a time, showing only clear and straight-forward correlations. Instead, when considering the whole data set, the regression analyses revealed that for both soil layers $\mathrm{Cu}$ was an important predictor for $\mathrm{N}_{2} \mathrm{O}$ production, more significantly in the surface soil layer than in the deeper soil layer (Table 3.). Previous studies have shown that ammonium oxidation contributes to $\mathrm{N}_{2} \mathrm{O}$ production in forested peat soil (Liimatainen et al., 2014), especially in the uppermost peat horizon (Regina et al., 1998b). The importance of ammonium oxidation for $\mathrm{N}_{2} \mathrm{O}$ production in peat soils with low $\mathrm{C} / \mathrm{N}$ ratio and water table has been shown also for subarctic peatlands (Gil Lugo, 2017). There, the relative contribution of nitrification and denitrification to the $\mathrm{N}_{2} \mathrm{O}$ emissions depend on peat moisture conditions; the role of nitrification is higher during dry summers when the peat water content is low (Gil Lugo, 2017). The studies mentioned above (Desloover et al., 2012; Gil Lugo, 2017; Liimatainen et al., 2014; Regina et al. 1998a,b; Thompson et al., 2012) and the positive relationship between the $\mathrm{Cu}$ content and $\mathrm{N}_{2} \mathrm{O}$ production observed here points to the potential role of ammonium oxidizers for $\mathrm{N}_{2} \mathrm{O}$ production in peat soils.

Soil $\mathrm{pH}$ can affect the overall denitrification activity and the ratio of 
$\mathrm{N}_{2} \mathrm{O}$ to $\mathrm{N}_{2}$ produced (Richardson et al., 2009). Moreover, nitrification processes are regulated by soil $\mathrm{pH}$, but as pointed out above, the organisms involved in nitrification and the factors regulating nitrification in acidic soils are poorly known. In our study, focusing on nutrient rich sites, soil $\mathrm{pH}$ did not correlate with $\mathrm{N}_{2} \mathrm{O}$ production or $\mathrm{N}_{2} \mathrm{O}$ emissions in either PCA or correlation analyses. These findings are in contrast to the results obtained by Regina et al. (1996), studying both nutrient poor and nutrient rich peatlands, and Weslien et al. (2009) in forested organic soils, both studies showing a strong positive correlation with $\mathrm{pH}$. In accordance with our results, Maljanen et al. (2010a) found no significant correlation between the $\mathrm{pH}$ and $\mathrm{N}_{2} \mathrm{O}$ flux, even though their data set included a larger number of sites than in studies by Regina et al. (1996) and Weslien et al. (2009).

\subsection{The effect of land-use history and soil characteristics on nitrous oxide} emissions

The land-use history affects the grouping of the peatland sites in the PCA: all land-use types, except the cultivated fields, formed rather coherent groups (Fig. 6) based on their management intensity and geographical origin (others vs. Iceland, see below). However, as pointed out above, $\mathrm{N}_{2} \mathrm{O}$ emissions largely varied within each land-use group (Table 1).

The physical, chemical and biological properties of the cultivated peatlands differ from their original state depending on the variable drainage, fertilization and management histories. Nitrous oxide emissions also varied within agricultural sites, which were all fertilized at some point in their history, but the management type and intensity vary. The highest emissions occurred from present $\left(C_{S}\right)$ and past $\left(A_{L}\right)$ agricultural sites (Table 1 ), that also displayed the highest $\mathrm{P}$ contents likely due to their fertilization history. The PCA analysis shows the differences in the nutrient status between study sites reflecting the results from element analyses (Table S2) in a visual form. As seen in the element analyses, also in the PCA analysis the site $\mathrm{C}_{\mathrm{K}}$ differed from other sites, especially in terms of nutrient concentrations in the soil. This site had an exceptionally long cultivation history (100 years) with heavy fertilization (Regina et al., 2004).

The Icelandic sites $\mathrm{C}_{I}$ and $\mathrm{D}_{\mathrm{I}}$ have to be regarded separately from the sites in other Nordic countries in terms of their $\mathrm{N}_{2} \mathrm{O}$ emissions (Fig. 6). These soils experience frequent volcanic ash deposition which influences the general soil chemical characteristics and favors the formation of stable aluminum-humus complexes typical for Icelandic wetland soils. Compared to those from other sites, Icelandic soils differed in nutrient composition and isotopic composition, being ${ }^{13} \mathrm{C}$ enriched (as the volcanic C, see Rizzo et al., 2014) and ${ }^{15} \mathrm{~N}$ depleted The Icelandic soils had low $\mathrm{P}$ content, gross nitrification rates and MBC, which explain their low $\mathrm{N}_{2} \mathrm{O}$ emissions.

\section{Conclusions}

Besides the water table level, the soil $\mathrm{C} / \mathrm{N}$ ratio is a known key regulator of $\mathrm{N}_{2} \mathrm{O}$ emissions from drained peatlands. Our study shows, however, that the peat $\mathrm{C} / \mathrm{N}$ ratio does not adequately predict either $\mathrm{N}_{2} \mathrm{O}$ production or $\mathrm{N}_{2} \mathrm{O}$ emissions in managed peatland soils. Although all study sites had a low $\mathrm{C} / \mathrm{N}$ ratio traditionally predicting high $\mathrm{N}_{2} \mathrm{O}$ emissions, the $\mathrm{N}_{2} \mathrm{O}$ emissions varied greatly within and between landuse groups. Thus, our study provides valuable insights into the regulatory factors underlying the variability in $\mathrm{N}_{2} \mathrm{O}$ emissions in drained peatlands. Most importantly, our findings show that an increased $\mathrm{P}$ content promotes $\mathrm{N}_{2} \mathrm{O}$ emissions, implying that a lack of $\mathrm{P}$ could limit $\mathrm{N}_{2} \mathrm{O}$ production and emissions. Interestingly, our study also indicates that increased $\mathrm{Cu}$ concentrations in peat may lead to enhanced $\mathrm{N}_{2} \mathrm{O}$ production and emissions, suggesting that ammonium oxidizing nitrifiers contribute to $\mathrm{N}_{2} \mathrm{O}$ production in managed peatlands. Our study sheds light upon the link between $\mathrm{N}_{2} \mathrm{O}$ emissions and soil $\mathrm{P}$ and $\mathrm{Cu}$ availability in managed northern peatlands, and highlights the strong coupling of the soil $\mathrm{N}$ and $\mathrm{P}$ cycles in peatland ecosystems.

\section{Acknowledgements}

Seppo Vihanta and Tobias Rütting are acknowledged for providing soil samples for the experiments. Hanne Vainikainen is acknowledged for her assistance in the laboratory work. Christina Biasi, Simo Jokinen, Jenie Gil and Maija Marushchak are appreciated for helping and sharing their knowledge relating to the ${ }^{15} \mathrm{~N}$ pool dilution analyses. We want to thank Hannu Nykänen for analyzing the $\mathrm{C} / \mathrm{N}$-ratios and isotopic values of bulk soil and Matti Pessi for analyzing DOC samples. Claire Treat read the manuscript and gave valuable comments. This study was part of the research project of MYRKLIMA (Mitigation of climate change impacts of cultivated peat soils) funded by the Ministry of Agriculture and Forestry in Finland (1036/312/2010). This work was also supported by North Savo Regional Fund, Niemi Foundation, Olvi Foundation, Finnish Concordia Fund, Faculty of Science and Forestry in University of Eastern Finland and Suoviljelysyhdistys (grants to M.L.) as well as Emil Aaltonen Foundation (grant to C.V.).

\section{Appendix A. Supplementary data}

Supplementary data related to this article can be found at http://dx. doi.org/10.1016/j.soilbio.2018.04.006.

\section{References}

Amador, J.A., Jones, R.D., 1993. Nutrient limitations on microbial respiration in peat soils with different total phosphorus content. Soil Biology and Biochemistry 25, 793-801.

Anderson, J.P.E., Domsch, K.H., 1978. A physiological method for the quantitative measurement of microbial biomass in soils. Soil Biology and Biochemistry 10, $215-221$.

Bateman, E.J., Baggs, E.M., 2005. Contributions of nitrification and denitrification to $\mathrm{N}_{2} \mathrm{O}$ emissions from soils at different water-filled pore space. Biology and Fertility of Soils 41, 379-388.

Björk, R.G., Ernfors, M., Sikström, U., Nilsson, M.B., Andersson, M.X., Rütting, T., Klemedtsson, L., 2010. Contrasting effects of wood ash application on microbial community structure, biomass and processes in drained forested peatlands. FEMS Microbiology Ecology 73, 550-562.

Brooks, P.D., Stark, J.M., McInteer, B.B., Preston, T., 1989. Diffusion method to prepare soil extracts for automated nitrogen-15 analysis. Soil Science Society of America Journal 53, 1707-1711.

Butterbach-Bahl, K., Baggs, E.M., Dannenmann, M., Kiese, R., Zechmeister-Bolterstern, S. 2013. Nitrous oxide emissions from soils: how well do we understand the processes and their controls? Philosophical Transactions of the Royal Society B 368, 20130122.

Callesen, I., Nilsson, L.O., Schmidt, I.K., Vesterdal, L., Ambus, P., Christianssen, J.O., Högberg, P., Gundersen, P., 2013. The natural abundance of ${ }^{15} \mathrm{~N}$ in litter and soil profiles under six temperate tree species: $\mathrm{N}$ cycling depends on tree species traits and site fertility. Plant and Soil 368, 375-392.

Canfield, D.E., Glazer, A.N., Falkowski, P.G., 2010. The evolution and future of Earth's nitrogen cycle. Science 330, 192-196.

Davidson, E.A., 2012. Representative concentration pathways and mitigation scenarios for nitrous oxide. Environmental Research Letters 7024005.

De Boer, W., Kowalchuk, G.A., 2001. Nitrification in acid soils: micro-organisms and mechanisms. Soil Biology and Biochemistry 33, 853-866.

Desloover, J., Vlaeminck, S.E., Clauwaert, P., Verstraete, W., Boon, N., 2012. Strategies to mitigate $\mathrm{N}_{2} \mathrm{O}$ emissions from biological nitrogen removal systems. Current Opinion in Biotechnology 23, 474-482.

Fowler, D., Pilegaard, K., Sutton, M.A., Ambus, P., Raivonen, M., Duyzer, J., Simpson, D., Fagerli, H., Fuzzi, S., Schjoerring, J.K., Granier, C., Neftel, A., Isaksen, I.S.A., Laj, P., Maione, M., Monks, P.S., Burkhardt, J., Daemmgen, U., Neirynck, J., Personne, E., Wichink-Kruit, R., Butterbach-Bahl, K., Flechard, C., Tuovinen, J.P., Coyle, M., Gerosa, G., Loubet, B., Altimir, N., Gruenhage, L., Ammann, C., Cieslik, S., Paoletti, E., Mikkelsen, T.N., Ro-Poulsen, H., Cellier, P., Caper, J.N., Horvãth, L., Loreto, F., Niinemets, Ü., Palmer, P.I., Rinne, J., Misztal, P., Nemitz, E., Nilsson, D., Pryor, S., Gallagher, M.W., Vesala, T., Skiba, U., Brüggemann, N., Zechmeister-Boltenstern, S., Williams, J., O'Dowd, C., Facchini, M.C., de Leeuw, G., Flossman, A., Chaumerliac, N., Erisman, J.W., 2009. Atmospheric composition change: ecosystems-atmosphere interactions. Atmospheric Environment 43, 5193-5267.

Gilch, S., Meyer, O., Schmidt, J., 2009. A soluble form of ammonia monooxygenase in Nitrosomonas europaea. Journal of Biological Chemistry 390, 863-873.

Gil Lugo, J.A., 2017. Microbial Processes Responsible for the High N2O Emissions from Sub-arctic Permafrost Peatlands and Tropical Soils as Determined by Stable Isotope Approach. Publications of the University of Eastern Finland Dissertations in Forestry and Natural Sciences. No. 297. ISBN: 978-952-61-2693-7.

Grömping, U., 2006. Relative importance for linear regression in R: the Package relaimpo. 
Journal of Statistical Software 17, 1-27.

Gütlein, A., Gerschlauer, F, Kikoti, I., Kiese, R., 2017. Impacts of climate and land use on $\mathrm{N}_{2} \mathrm{O}$ and $\mathrm{CH}_{4}$ fluxes from tropical ecosystems in the Mt. Kilimanjaro region, Tanzania. Global Change Biology 24, 1239-1255.

Hart, S.C., Nason, G.E., Myrold, D.D., 1994. Dynamics of gross nitrogen transformations in old-growth forest: the carbon connection. Ecology 75, 880-891.

Holz, M., Aurangojeb, M., Kasimir, Å., Boeckx, P., Kuzyakov, Y., Klemedtsson, L., Rütting, T., 2015. Gross nitrogen dynamics in the mycorrhizosphere of an organic forest soil. Ecosystems 19, 284-295.

Högberg, P., Johansson, C., 1993. ${ }^{15} \mathrm{~N}$ abundance of forests is correlated with losses of nitrogen. Plant and Soil 157, 147-150.

IPCC, 2013. In: Stocker, T.F., Qin, D., Plattner, G.-K., Tignor, M., Allen, S.K., Boschung, J., Nauels, A., Xia, Y., Bex, V., Midgley, P.M. (Eds.), Climate Change 2013: the Physical Science Basis. Contribution of Working Group I to the Fifth Assessment Report of the Intergovernmental Panel on Climate Change. Cambridge University Press, Cambridge, United Kingdom and New York, NY, USA, pp. 1535.

Kasimir-Klemedtsson, Å., Klemedtsson, L., Berglund, K., Martikainen, P., Silvola, J., Oenema, O., 1997. Greenhouse gas emissions from farmed organic soils: a review. Soil Use \& Management 13, 245-250.

Kassambara, A., Mundt, F., 2016. Factoextra: Extract and Visualize the Results of Multivariate Data Analyses. R package version 1.0.3. http://CRAN.R-project.org/ package $=$ factoextra.

Khalil, K., Mary, B., Renault, P., 2004. Nitrous oxide production by nitrification and denitrification in soil aggregates as affected by $\mathrm{O}_{2}$ concentration. Soil Biology and Biochemistry 36, 687-699.

Kirkham, D., Bartholomew, W.V., 1954. Equations for following nutrient transformations in soil, utilizing tracer data. Soil Science Society of America Journal 18, 33-34.

Kirkham, D., Bartholomew, W.V., 1955. Equations for following nutrient transformations in soil, utilizing tracer data: II. Soil Science Society of America Journal 19, 189-192.

Klemedtsson, L., von Arnold, K., Weslien, P., Gundersen, P., 2005. Soil CN ratio as a scalar parameter to predict nitrous oxide emissions. Global Change Biology 11, 1142-1147.

Klemedtsson, L., Ernfors, M., Björk, R.G., Weslien, P., Rütting, T., Crill, P., Sikström, U., 2010. Reduction of greenhouse gas emissions by wood ash application to a Picea abies (L.) Karst. forest on a drained organic soil. European Journal of Soil Science 61, 734-744.

Köchy, M., Hiederer, R., Freibauer, A., 2015. Global distribution of soil organic carbon Part 1: masses and frequency distributions of SOC stocks for the tropics, permafrost regions, wetlands, and the world. SOIL 1, 351-365.

Lê, S., Josse, J., Husson, F., 2008. FactoMineR: an R package for multivariate analysis. Journal of Statistical Software 25, 1-18.

Leppelt, T., Dechow, R., Gebbert, S., Freibauer, A., Lohila, A., Augustin, J., Frösler, M. Fiedler, S., Glatzel, S., Höper, H., Järveoja, J., Lærke, J., Maljanen, M., Mander, Ü., Mäkiranta, P., Minkkinen, K., Ojanen, P., Regina, K., Strömgren, M., 2014. Nitrous oxide emission budgets and land-use-driven hotspots for organic soils in Europe. Biogeosciences 11, 6596-6612.

Liimatainen, M., Martikainen, P.J., Maljanen, M., 2014. Why granulated wood ash decreases $\mathrm{N}_{2} \mathrm{O}$ production in boreal acidic peat soil? Soil Biology and Biochemistry 79, $140-148$.

Lohila, A., Aurela, M., Regina, K., Laurila, T., 2003. Soil and total ecosystem respiration in agricultural fields: effect of soil and crop type. Plant and Soil 251, 303-317.

Luxhøi, J., Nielsen, N.E., Jensen, L.S., 2004. Effect of soil heterogeneity on gross nitrogen mineralization measured by ${ }^{15} \mathrm{~N}$-pool dilution techniques. Plant and Soil 262, 263-275.

Maljanen, M., Virkajärvi, P., Hytönen, J., Öquist, Ö., Sparrman, T., Martikainen, P.J., 2009. Nitrous oxide production in boreal soils with variable organic matter at low temperature - snow manipulation experiment. Biogeosciences 6, 2461-2473.

Maljanen, M., Sigurdsson, B.D., Guðmundsson, J., Óskarsson, H., Huttunen, J.T., Martikainen, P.J., 2010a. Greenhouse gas balances of managed peatlands in the Nordic countries - present knowledge and gaps. Biogeosciences 7, 2711-2738.

Maljanen, M., Hytönen, J., Martikainen, P.J., 2010b. Cold-season nitrous oxide dynamics in a drained boreal peatland differ depending on land-use practice. Canadian Journal of Forest Research 40, 565-572.

Maljanen, M., Shurpali, N., Hytönen, J., Mäkiranta, P., Aro, L., Potila, H., Laine, J., Li, C., Martikainen, P.J., 2012. Afforestation does not necessarily reduce nitrous oxide emissions from managed boreal peat soils. Biogeochemistry 108, 199-218.

Maljanen, M., Liimatainen, M., Hytönen, J., Martikainen, P.J., 2014. The effect of granulated wood-ash fertilization on soil properties and greenhouse gas (GHG) emissions in boreal peatland forests. Boreal Environment Research 19, 295-309.

Martikainen, P.J., Nykänen, H., Crill, P., Silvola, J., 1993. Effect of a lowered water table on nitrous oxide fluxes from northern peatlands. Nature 366, 51-53.

Marushchak, M.E., Pitkämäki, A., Koponen, H., Biasi, C., Seppälä, M., Martikainen, P.J., 2011. Hot spots for nitrous oxide emissions found in different types of permafrost peatlands. Global Change Biology 17, 2601-2614.

Mehnaz, K.R., Dijkstra, F.A., 2016. Denitrification and associated $\mathrm{N}_{2} \mathrm{O}$ emissions are limited by phosphorus availability in a grassland soil. Geoderma 284, 34-41.

Moilanen, M., Hytönen, J., Hökkä, H., Ahtikoski, A., 2015. Fertilization increased growth of Scots pine financial performance of forest management in a drained peatland in Finland. Silva Fennica 49, 1301

Myhre, G., Shindell, D., Bréon, F.-M., Collins, W., Fuglestvedt, J., Huang, J., Koch, D., Lamarque, J.-F., Lee, D., Mendoza, B., Nakajima, T., Robock, A., Stephens, G., Takemura, T., Zhang, H., 2013. In: Stocker, T.F., Qin, D., Plattner, G.-K., Tignor, M., Allen, S.K., Boschung, J., Nauels, A., Xia, Y., Bex, V., Midgley, P.M. (Eds.), Anthropogenic and Natural Radiative Forcing. in: Climate Change 2013: the Physical
Science Basis. Contribution of Working Group I to the Fifth Assessment Report of the Intergovernmental Panel on Climate Change. Cambridge University Press, Cambridge, United Kingdom and New York, NY, USA.

Myllys, M., Sinkkonen, M., 2004. Viljeltyjen turve- ja multamaiden pinta-ala ja alueellinen jakauma Suomessa. Summary: the area and distribution of cultivated peat soils in Finland. Suo 55, 53-60.

Ojanen, P., Minkkinen, K., Alm, J., Penttilä, T., 2010. Soil-atmosphere $\mathrm{CO}_{2}, \mathrm{CH}_{4}$ and $\mathrm{N}_{2} \mathrm{O}$ fluxes in boreal forestry-drained peatlands. Forest Ecology and Management 260, $411-421$.

Ravishankara, A.R., Daniel, J.S., Portmann, R.W., 2009. Ozone-depleting substance emitted in the $21^{\text {st }}$ century. Science $326,123-125$.

R Core Team, 2015. R: a Language and Environment for Statistical Computing. R Foundation for Statistical Computing.

Regina, K., Nykänen, H., Silvola, J., Martikainen, P.J., 1996. Fluxes of nitrous oxide from boreal peatlands as affected by peatland type, water table level and nitrification capacity. Biogeochemistry 35, 401-408.

Regina, K., Nykänen, H., Maljanen, M., Silvola, J., Martikainen, P.J., 1998a. Emissions of $\mathrm{N}_{2} \mathrm{O}$ and $\mathrm{NO}$ and net nitrogen mineralization in a boreal forested peatland treated with different nitrogen compounds. Canadian Journal of Forest Research 28, $132-140$.

Regina, K., Silvola, J., Martikainen, P.J., 1998b. Mechanisms of $\mathrm{N}_{2} \mathrm{O}$ and NO production in the soil profile of a drained and forested peatland, as studied with acetylene, nitrapyrin and dimethyl ether. Biology and Fertility of Soils 27, 205-210.

Regina, K., Syväsalo, E., Hannukkala, A., Esala, M., 2004. Fluxes of $\mathrm{N}_{2} \mathrm{O}$ from farmed peat soils in Finland. European Journal of Soil Science 55, 591-599.

Regina, K., Sheehy, J., Myllys, M., 2015. Mitigating greenhouse gas fluxes from cultivated organic soils with raised water table. Mitigation and Adaptation Strategies for Global Change 20, 1529-1544.

Richardson, D., Felgate, H., Watmough, N., Thomson, A., Baggs, E., 2009. Mitigating release of the potent greenhouse gas $\mathrm{N}_{2} \mathrm{O}$ from the nitrogen cycle - could enzymic regulation hold the key? Trends in Biotechnology 27, 388-397.

Rizzo, A.L., Jost, H.-J., Caracausi, A., Paonita, A., Liotta, M., Martelli, M., 2014. Real-time measurements of the concentration and isotope composition of atmospheric and volcanic $\mathrm{CO}_{2}$ at Mount Etna (Italy). Geophysical Research Letters 41, 2382-2389.

Šimek, H., Cooper, J.E., 2002. The influence of soil pH on denitrification: progress towards the understanding of this interaction over the last 50 years. European Journal of Soil Science 53, 345-354.

Stark, J.M., Firestone, M.K., 1995. Mechanisms for soil moisture effects on activity of nitrifying bacteria. Applied and Environmental Microbiology 61, 218-221.

Stark, J.M., Hart, S.C., 1997. High rates of nitrification and nitrate turnover in undisturbed coniferous forests. Nature 385, 61-64.

Statistics Finland, 2017. Greenhouse Gas Emissions in Finland 1990-2015. National Inventory Report Under the UNFCCC and the Kyoto Protocol Available at: http:// www.tilastokeskus.fi/tup/khkinv/khkaasut raportointi en.html.

Strack, M. (Ed.), 2008. Peatlands and Climate Change. International Peat Society, Saarijärven Offset Oy, Jyväskylä, Finland, pp. 223.

Thompson, A.J., Giannopulos, G., Pretty, J., Baggs, E.M., Richardson, D.J., 2012. Biological sources and sinks of nitrous oxide and strategies to mitigate emissions. Philosophical Transactions of the Royal Society B 367, 1157-1168.

Tiemeyer, B., Borraz, E.A., Augustin, J., Bechtold, M., Beetz, S., Beyer, C., Drösler, M., Ebli, M., Eickenscheidt, T., Fieldler, S., Förster, C., Freibauer, A., Giebels, M., Glatzel, S., Heinichen, J., Hoffmann, M., Höper, H., Jurasinki, G., Leiber-Sauheitl, K., PeichlBrak, M., Roßkopf, N., Sommer, M., Zeitz, J., 2016. High emissions of greenhouse gases from grasslands on peat and other organic soils. Global Change Biology 22, 4134-4149.

Ullah, B., Shaaban, M., Rong-gui, H.U., Jin-song, Z., Shan, L., 2016. Assessing soil nitrous oxide emission as affected by phosphorus and nitrogen addition under two moisture levels. Journal of Integrative Agriculture 15, 2865-2872.

Venables, W.N., Ripley, B.D., 2002. Modern Applied Statistics with S, fourth ed. Springer, New York, pp. 498 ISBN 0-387-95457-0.

Verchot, L.V., Holmes, Z., Mulon, L., Groffman, P.M., Lovett, G.M., 2001. Gross vs. net rates of $\mathrm{N}$ mineralization and nitrification as indictors of functional difference between forest types. Soil Biology and Biochemistry 33, 1889-1901.

Vitousek, P.M., Aber, J.D., Howarth, R.W., Likens, G.E., Matson, P.A., Schindler, D.W., Schlesinger, W.H., Tilman, D.G., 1997. Human alteration of the global nitrogen cycle: sources and consequences. Ecological Applications 7, 737-750.

von Post, L., 1922. Sveriges Geologiska Undersöknings torvinventering och några av dess hittils vunna resultat. Svenska Mosskulturföreningens Tidskrift 37, 1-27.

Wall, A., Heiskanen, J., 2009. Soil-water content and air-filled porosity affect height growth of Scots Pine in afforested arable land in Finland. Forest Ecology and Management 257, 1751-1756.

Wang, F., Li, J., Wang, X., Zhang, W., Zou, B., Neher, D.A., Li, Z., 2014. Nitrogen and phosphorus addition impact soil $\mathrm{N}_{2} \mathrm{O}$ emissions in a secondary tropical forest of South China. Scientific Reports 4, 5616.

Weslien, P., Kasimir Klemedtsson, A., Börjesson, G., Klemedtsson, L., 2009. Strong pH influence on $\mathrm{N}_{2} \mathrm{O}$ and $\mathrm{CH}_{4}$ fluxes from forested organic soils. European Journal of Soil Science 60, 311-320.

Westbrook, C.J., Devito, K.J., 2004. Gross nitrogen transformations in soils from uncut and cut upland and peatland coniferous forest stands. Biogeochemistry $68,33-50$

Wrage, N., Velthof, G.L., van Beusichem, M.L., Oenema, O., 2001. Role of nitrifier denitrification in the production of nitrous oxide. Soil Biology and Biochemistry 33, 1723-1732. 